\title{
PODEM AÇÕES MORAIS SER BELAS? SOBRE A POSSIBLIDADE DE UMA ESTÉTICA MORAL A PARTIR DE DAVID HUME $^{1}$
}

Daniel de Vasconcelos Costa (UFRJ) $)^{2,3}$

danieldevcosta@gmail.com

Resumo: $\mathrm{O}$ presente artigo tem como objetivo defender a possibilidade da existência da beleza moral a partir de abordagens analíticas contemporâneas da estética e da teoria moral e estética de David Hume. Diferentes relações entre a estética e a moralidade serão analisadas, na primeira parte. A hipótese da beleza moral será colocada como uma destas possíveis relações. Dentro das possibilidades de se fundamentar a beleza moral, será argumentado que a melhor seria através de uma compreensão humeana da estética e da moralidade. A segunda parte do artigo analisa o conceito de experiência estética e a sua importância para a fundamentação humeana da beleza moral. Por fim, a teoria moral e estética proposta por Hume será desenvolvida a fins de demonstrar como a hipótese da beleza moral poderia ser justificada.

Palavras-chave: beleza moral; experiência estética; estética moral em David Hume; estética analítica contemporânea.

\section{INTRODUÇÃO}

Uma das reações mais espontâneas que os seres humanos vivenciam seria a de encontrar beleza em objetos e eventos

\footnotetext{
${ }^{1}$ Recebido: 15-07-2020/ Aceito: 05-01-2021/ Publicado online: 15-04-2021.

${ }^{2}$ Pós-doutor pela Universidade Federal do Rio de Janeiro (UFRJ), Rio de Janeiro, RJ, Brasil.

${ }^{3}$ ORCID: https://orcid.org/0000-0001-9724-8229.
} 
no mundo. ${ }^{4}$ Observamos e afirmamos que certas paisagens, pessoas, roupas, prédios, e diversos outros objetos do nosso cotidiano, sejam eles dados pela natureza ou criados pelas mãos humanas, possuem beleza. Apreciamos esses objetos com uma diferente atenção comparada à que damos aos demais objetos de nossa vida cotidiana e atribuímos a eles propriedades que expressariam a sua beleza. Além disso, temos diferentes reações emocionais frente aos objetos ou eventos que possuiriam beleza, que vão desde uma experiência emocional, como chorar ou sentir satisfação, a um mero reconhecimento sóbrio de que o objeto ou evento em questão teria uma propriedade de beleza. ${ }^{5}$ Nos casos em que objetos foram construídos de forma a possuírem propriedades de beleza e para proporcionarem um tipo de experiência estética, convencionou-se chamá-los de "obras de arte", e no caso de eventos, de "performances artísticas".

Parece ser trivial afirmar que, enquanto obras de arte e performances artísticas apresentariam propriedades estéticas, há inúmeros objetos e eventos no mundo que não as possuiriam. Normalmente, não atribuiríamos propriedades estéticas a remédios ou lâmpadas, p.ex., assim como não diríamos que escovar os dentes ou assistir a um programa na televisão seriam passíveis de apreciação estética. Entretanto,

\footnotetext{
${ }^{4}$ Entendo por "beleza" uma categoria geral do juízo estético que envolve diferentes propriedades, inclusive contraditórias, tais como: "belo", "feio", "bonito", "horroroso", "sublime", "mundano", "saboroso", "desagradável", etc.

${ }^{5}$ Para fins do presente artigo, podemos chamar as mais diferentes propriedades de beleza como "propriedades estéticas" e a sua atribuição a certos objetos por um sujeito como "juízo estético". Por sua vez, as reações emotivas causada pelos objetos aos quais atribuímos esses propriedades podemos chamar de "experiência estética". Por fim, podemos denominar de "apreciação estética" o momento em que temos a experiência estética e realizamos um juízo estético.

${ }^{6}$ Deve ser notado, contudo, que essa visão acerca das obras de arte seria somente uma visão entre várias, no caso, a concepção estética da arte.
} 
embora não possamos afirmar que estes objetos ou eventos mundanos poderiam ser percebidos como obras de arte ou performances artísticas, isso não significa que não possamos apreciá-los esteticamente e atribuí-los propriedades estéticas (SAITO, 2001; IRVIN, 2008, p. 30-32). Ao contrário, ainda que a apreciação estética de certos objetos ou eventos possa ser bem incomum, atribuímos beleza aos mais diferentes objetos e eventos do nosso cotidiano, desde uma mera caneta a um fenômeno da natureza. Uma das apreciações estéticas de eventos cotidianos mais interessante seria a dos fenômenos morais.

Não é incomum atribuirmos diferentes propriedades estéticas a atos ou eventos que consideramos morais ou imorais. Dizemos que as ações de certos grupos em prol de outros seriam "bonitas", como, p.ex., a ajuda a grupos que se encontram em condição de vulnerabilidade. Inversamente, dizemos que o maltrato a certos grupos seria "feio", e, até mesmo, "horroroso", como o genocídio. Sabemos que eventos morais possuiriam beleza por sermos tomados por certas emoções ao observá-los. A experiência estética de eventos morais abre o caminho para a atribuição de propriedades deste tipo a eles. Eventos morais que apresentassem qualidades estéticas possuiriam o que podemos chamar de beleza moral (PARIS, 2018a; 2018b).

Contudo, embora parte da nossa linguagem moral envolva propriedades estéticas, não é claro como eventos morais poderiam apresentá-las. Com isso, podemos colocar a seguinte questão: como um evento que possuiria propriedade morais, poderia, também, possuir propriedades estéticas?

$\mathrm{O}$ presente artigo busca defender o que poderia ser de- 
nominado de hipótese da beleza moral. Esta hipótese seria a de que temos experiências estéticas ao termos contato com certos eventos morais, e que, por isso, poderíamos atribuir qualidades estéticas a estes eventos morais. Para tanto, partiremos do entendimento analítico contemporâneo da experiencia estética em conjunto com a proposta estética e moral humeana para, assim, demonstrar como a beleza moral seria possível.

$\bigcirc$ primeiro passo que devemos dar é o de delimitar o objeto da nossa investigação, em especial, circunscrevendo qual relação entre a estética e a moralidade que desejamos analisar (I). O segundo passo seria o de abordar o conceito de experiência estética como proposto por alguns autores da estética analítica contemporânea (II). Por fim, veremos o tratamento dado por Hume à apreciação e à experiência estética, assim como a sua relação com as bases da moralidade (III).

\section{Aspectos dA RELAÇÃO ENTRE A MORALIDADE E A ESTÉTICA}

As questões acerca da relação entre a arte e moralidade são antigas, e podem ser encontradas já em Platão e Aristóteles. De acordo com a leitura mais habitual, teríamos em Platão uma crítica às artes representacionais, ou miméticas, por elas serem nada mais que uma "cópia da cópia", o que poderia, por conseguinte, distorcer a nossa busca por conhecimento $(2017$, p. 595a).? As distorções criadas por es-

\footnotetext{
${ }^{7}$ Há diferentes aspectos do argumento de Platão sobre a poesia no A República que enseja um grande debate acerca do que ele buscou defender ou se o que ele teria dito seria defensável. SteCont.
} 
te tipo de arte poderiam gerar opiniões falsas sobre a realidade, inclusive sobre o que seria, genuinamente, certo e errado em termos morais (JANAWAY, 2013). Esta distorção teria consequências importantes para a sociedade, que são expostas, principalmente, ao fim do livro II e ao longo do livro III de A República (2017, p. 376e-417b). Ao discutir a pedagogia adequada para a classe dos guardiões, Platão acentua a capacidade educativa das artes, em especial, da poesia, para a construção do caráter de uma pessoa. Porém, ele argumenta, se observássemos as poesias dos grandes poetas, como Hesíodo e Homero, perceber-se-ia que elas estariam completas de falsidades sobre a realidade e a moralidade e que esses ensinamentos influenciariam as disposições dos cidadãos e dos guardiões. Além disso, o processo de recitar poesias contribuiria para a formação das disposições, pois ao colocar-se no lugar do outro, inclusive de um personagem literário, envolve, entre outras coisas, entender o seu ponto de vista. Este processo de entender o

phen Halliwell reconhece que há uma crítica à poesia mimética nos livros II, III e X do diálogo A República. Contudo, ele defende que a busca de fundamentar a afirmação de que Platão teria uma visão completamente crítica da poesia somente a partir deste diálogo ignora inúmeros outros que, em parte, abordam a mesma temática como os Apologia de Sócrates, Eutífron, Íon e Crátilo, que demonstrariam que a compreensão sobre a poesia e a mimesis por Platão iria além do que foi exposto no A República (HALLIWELL, 2002, p. 37-117; HALLIWELL, 2002). Por sua vez, Julia Annas (1981, p. 336-338) aponta para os inúmeros problemas nos argumentos colocados por Platão, em especial, a dificuldade de reconciliar os livros II e III com o X, pois nos dois primeiros a poesia criticada seria aquela que apresentaria aspectos miméticos, e não todo tipo de poesia, enquanto no livro $\mathrm{X}$, a noção de mimesis parece ter referência além daquela poesia que nos convida a representar os seus personagens, mas mesmo as narrativas seriam miméticas ao reproduzirem aspectos da realidade. Duas defesas das críticas de Platão a poesia no A República e na consistência da sua argumentação podem ser encontradas em Eric Havelock (1963) e Jessica Moss (2007). À luz desta discussão, podemos, ainda assim, defender que, indiferente se a crítica de Platão seria consistente ou se ele teria uma compreensão sobre a poesia e a mimesis distinta do que apresentada no A República, não pode ser negado que há, neste diálogo, uma crítica moral à poesia e, inclusive, às artes representacionais como um todo. 
outro poderia ter como resultado uma confusão individual acerca do que seria realmente correto e errado (ANNAS, 1981, p. 96-98).

Por sua vez, Aristóteles se absteve de realizar críticas e buscou sistematizar as artes representacionais, em especial, o teatro (ARISTOTLE, 1987). Ao buscar dizer o que elas seriam e a sua função, Aristóteles cria uma conexão entre as nossas emoções e a arte. A arte é capaz de criar emoções em nós, e, quando bem construída, atingimos o seu ápice com a catarse, o expurgo das emoções vividas, gerando prazer na audiência (LEAR, 1988, p. 323-326). Uma das interpretações mais aceitas afirma que, para Aristóteles, essa relação entre a arte e as emoções seria capaz de gerar aprendizados e uma construção do caráter, dada a conexão entre moralidade e as emoções (NUSSBAUM, 2001, p. 378-394; CRITTENDEN, 1991).

A crítica platônica seria uma análise moral e política sobre a permissibilidade da arte na sociedade. Ele questiona os efeitos que as artes poderiam ter sobre os indivíduos e, por consequência, a sociedade. Não há realmente uma discussão acerca da importância da moralidade para a forma ou o conteúdo da arte. Ainda que seja uma crítica moral sobre a arte, ela não poderia ser chamada, propriamente, de uma crítica moral $d a$ arte. Não há uma discussão sobre a relevância da moralidade para a estética. A relação entre a estética e a moralidade seria, meramente, externa.

Ao contrário de seu antigo mestre, Aristóteles aponta para o fato de que, se a arte terá ou não um efeito sobre a sociedade, seria um mero fato contingente, e dependeria de como a arte teria sido construída. Se feita de forma ade- 
quada, a arte seria benéfica para a sociedade, pois ela seria um veículo de uma pedagogia moral dos cidadãos ao possibilitar a educação das suas emoções (JANKO, 1992). É, em Aristóteles, que podemos, então, observar que há uma conexão interna entre a moralidade e a arte, em especial, a tragédia, pois podemos julgar sua forma e seu conteúdo de acordo com a sua capacidade de educar moralmente os cidadãos (FREELAND, 1992). Há uma finalidade moral da arte, a de criar bons cidadãos, mas há, igualmente, uma crítica moral $d a$ arte, pois a moralidade se torna parte integral da arte. É a partir deste momento que podemos apontar para uma discussão moral sobre a estética.

A questão sobre a pedagogia moral através das artes é somente uma das questões possíveis acerca da relação entre a moralidade e estética. Além desta, podemos ver, ao menos, outras duas questões possíveis, a saber, que o valor estético seria dependente do valor moral (BEARDSMORE, 1971; CARROLL, 2001; KIERAN, 1996) e, como já dito, que eventos morais poderiam apresentar propriedades estéticas (MCGINN, 2003; GAUT, 2007; PARIS, 2018a). O nosso objeto de investigação é, exatamente, a terceira questão. Desta forma, somente nos focaremos sobre ela.

Bastaria observar nossa linguagem moral cotidiana para percebermos que há uma relação linguística entre a estética e a moralidade. Há muitos termos estéticos usados nos julgamentos morais. Ao chamar nossa atenção para o fato de que nossa linguagem moral cotidiana envolve o uso de termos estéticos e que eles enriquecem e possibilitam nuances que outros termos morais não possibilitam, o filósofo britânico Colin McGinn (2003, p. 98-99) afirma que: 
[...] de forma a avaliar esta teoria, é útil olhar para nossa linguagem ordinária da avaliação moral e notar como ela está completamente saturada de noções estéticas. [...] Na verdade, o nosso vocabulário para descrever o caráter de forma moral é bastante empobrecido se não incluirmos esses tipos de termos; e é notável, uma vez que se atente para isso, o quão comum é ouvir avaliações morais expressas nesses tipos de termos estéticos. ${ }^{8}$

A prática de atribuição de termos estéticos a eventos morais confere, ao menos, uma certa plausibilidade de que o que chamamos de beleza moral, realmente, exista.

Afirma-se, normalmente, que há duas categorias de termos na nossa linguagem moral. Uma dessas categorias seria a de termos deônticos, que se referem aos comandos e regras morais, e a outra seria a de termos valorativos ou axiológicos, que qualificam as ações, eventos e mesmo as pessoas. ${ }^{9}$ Mas, podemos observar que entre os termos morais valorativos há inúmeros que têm um teor estético (MCGINN, 2003, p. 92-93). Termos como "lindo", "feio", "doce", "repulsivo", entre vários outros, servem para designar um aspecto do comportamento ou do caráter de pessoas. Além disso, é muito comum que mães e pais façam uso

\footnotetext{
${ }^{8}$ As citações em sua língua original aparecerão nas notas de rodapé e a sua tradução no corpo do texto foi realizada pelo autor, quando não houve uma tradução oficial em português: [...] to evaluate this theory it helps to look at our ordinary language of moral appraisal and note how thoroughly saturated it is with aesthetic notions. [...] In fact, our vocabulary for describing character in morally evaluative ways is rather impoverished if we do not include these sorts of terms; and it is remarkable, once one attends to it, how common it is to hear moral appraisals expressed in these kinds of aesthetic terms.

${ }^{9}$ Outra forma de diferenciar os termos morais deônticos dos valorativos seria através do emprego linguístico desses termos. Comumente, os termos deônticos se apresentam em verbos ou locuções verbais, como "dever", "tem que", "poder", etc., ou ainda por substantivos, como "obrigação", "permissão", "dever", etc. (há uma exceção bem importante com relação aos termos "certo" e "errado", e correlativos, que são adjetivos). Há, ainda, a possibilidade da modalidade deôntica ser expressa por características sintáticas, como no modo imperativo. Por sua vez, é muito comum que os termos valorativos sejam expressos por adjetivos, como "bom", "ruim", "corajoso", etc.
} 
de termos estéticos como parte da educação moral de seus filhos, ao afirmar que certos eventos são feios e que, por isso, não deveriam ser realizados. P.ex., ao realizar o seu estudo sobre o julgamento moral das crianças, o psicólogo suíço Jean Piaget afirmou (1994, p. 217-218) que: "[...] se analisarmos a argumentação da criança, a razão última é sempre a proibição feita pelo adulto: é feio "colar", porque é enganar etc., e é feio enganar [...]."

Entretanto, da mesma forma como John L. Mackie (1990) já havia defendido que toda linguagem moral envolveria um erro linguístico, críticos da hipótese da beleza moral poderiam alegar que essa atribuição de termos estéticos a eventos morais seria um uso errôneo da linguagem estética. O filósofo Noël Carroll critica a ideia de beleza moral ao afirmar que, tal como a tradição lidou com o termo "beleza", este seria somente aplicável a objetos sensiveis, e, portanto, sua atribuição a eventos morais seria somente um erro categorial. A busca de atribuir beleza a eventos morais criaria, na verdade, um novo conceito, um que deve ser distinguido do conceito estético de beleza, que seria aplicável somente a objetos estéticos, como certas obras de arte (2000, p. 654655). Por sua vez, o filósofo Robert Stecker (2008, p. 200) critica a prática de atribuição de propriedades estéticas a eventos moral ao dizer que:

[...] filósofos, assim como pessoas comuns, às vezes falam de traços de caráter virtuosos como bonitos. Este é um argumento muito fraco. Devemos considerar esta fala como a atribuição de uma propriedade estética a estes traços ou devemos considerá-la mais metaforicamente, como um jeito de elogiá-los sem o compromisso de que possuam quaisquer outras qualidades? Sem um motivo mais 
substantivo para a alegação de beleza moral, isso é uma questão aberta. ${ }^{10}$

Stecker pede por uma teoria mais robusta da beleza moral, uma que possa explicar como os termos estéticos que atribuímos às obras de artes também poderiam ser atribuídos aos eventos morais, caso contrário, a crítica de erro categorial não poderia ser refutada. As críticas de Carroll e Stecker trazem pontos interessantes que devem ser respondidos, caso não queiramos que a hipótese da beleza moral seja uma "mera maneira de falar".

No entanto, devemos qualificar essa atribuição de propriedades estéticas a eventos morais. A hipótese da beleza moral não é a defesa de que podemos, meramente, atribuir propriedades morais e propriedades estéticas ao mesmo evento ou ato. Se fosse desta forma, seria uma tese trivial.

É inegável que atribuímos a um único objeto ou evento propriedades de diferentes categorias. Um copo, p.ex., pode ser pesado, grande, bem resistente, azul, etc. É igualmente plausível que possamos afirmar que um evento possua tanto propriedades morais quanto estéticas. Nestes casos, embora eventos fossem corretos e belos, não poderíamos afirmar que encontramos beleza moral neles. Esses eventos carregam ambas as propriedades sem que elas tenham qualquer conexão. Isso se demonstra por podermos, inclusive, facilmente subtrair as propriedades de um tipo sem que as propriedades do outro tipo tivessem que ser eliminadas.

\footnotetext{
${ }^{10}$ [...] philosophers as well as ordinary folk sometimes talk of virtuous character traits as beautiful. That is a very weak argument. Should we take this talk as ascribing an aesthetic property to these traits or should we take it more loosely as a way of praising them without a commitment to their possessing any further qualities? Without a more substantive reason for the moral beauty claim, it is an open question.
} 
Podemos pensar no seguinte caso. Um grupo de artistas realiza performances belíssimas para arrecadar alimentos para famílias em situação de vulnerabilidade. Talvez a grande maioria de nós considerasse tais performances como moralmente elogiável. No entanto, podemos dizer que essas performances são igualmente bonitas, pois os artistas a realizam com maestria e fazem com que o público, em sua maioria, possua experiências estéticas devido a elas. Tal como este caso foi descrito, poderíamos dizer que, ainda que propriedades morais e estéticas fossem atribuídas ao mesmo evento, às performances artísticas desse grupo, essas propriedades não possuem qualquer correlação, pois se esses mesmos artistas simplesmente tivessem feito uma campanha para arrecadar alimentos, sem qualquer performance artística, este ato seria moralmente equivalente ao primeiro, ainda que ele não tivesse as mesmas propriedades estéticas. Da mesma forma, diríamos que essa performance teria propriedades estéticas, ainda que não possuísse qualquer propriedade moral, caso tivesse sido realizada por motivação financeira.

Quando dizemos que um evento moral nos proporciona uma experiência estética, queremos dizer que este evento teria propriedades estéticas em virtude das propriedades morais, ou seja, se eliminarmos as propriedades morais deste evento ou ato, eliminamos também as suas propriedades estéticas. Há uma conexão entre ambas as propriedades. Tendo em vista essa prática de atribuição de propriedades estéticas a eventos morais, e que, por isso, tais eventos morais possuiriam uma beleza moral, cabe a seguinte questão: por que alguns eventos morais poderiam nos proporcionar experiências estéticas e, assim, possuiriam qualidades estéti- 
cas? Como a conexão entre ambas as propriedades se daria? Há, no mínimo, três possibilidades de explicar como a relação entre propriedades morais e estéticas poderia se dar. A primeira seria através de uma relação de identidade. A noção de identidade é complexa e tem uma longa história na filosofia, mas podemos dizer que, em termos bem simples, a relação entre as propriedades morais e as estéticas seria uma de identidade caso os seus termos se referissem à mesma propriedade e caso os termos estéticos e os termos morais possuíssem uma relação semântica, de forma que alguém soubesse que, ao afirmar que um evento seria bonito, ele também afirmaria que o evento seria correto, e vice versa. Embora relações de identidade não precisassem pressupor uma redução semântica dos termos morais aos estéticos ou dos termos estéticos aos morais, pois eles seriam diferentes aspectos da mesma propriedade, seria estranho imaginarmos uma relação de identidade entre propriedades morais e estéticas sem que os termos morais e os estéticos tivessem, ao menos, uma semântica interrelacionada que indicasse esta relação.

A possibilidade da identidade entre as propriedades morais e as estéticas poderia ser perseguida através do ideal de kalokagathia que tanto aparece nos escritos de diversos filósofos da antiga Grécia, entre eles, Platão e Aristóteles (JAEGER, 2013). O termo que os gregos empregaram para afirmar que algo possuiria beleza foi kalon. Este termo foi utilizado tanto em contextos morais quanto não morais, como aqueles que diziam respeito a corpos, a moral, a ordens funcionais corretamente realizadas, como as da natureza, do drama, da cidade, e, inclusive, a objetos abstratos, 
como os da matemática (IRWIN, 2010; DOVER, 1974, p. 69-73). Ao falar sobre a posição do kalon no corpus aristotelicum, T. H. Irwin (2010, p. 382) afirma que: "Aristóteles usa kalon tanto para abarcar a beleza quanto para abarcar a retidão moral, que ele reconhece como duas propriedades distintas." "Ele defende que a noção de kalon teria, de certa forma, um único significado, porém, com diferentes referências. Isto tornaria possível que diferentes tipos de coisas pudessem ser kalon por causa de diferentes tipos de propriedades basilares, entre elas, propriedades morais (2010, p. 395-396). ${ }^{12}$

Se postularmos que há diferentes propriedades que serviriam como base do kalon, tornar-se-ia perceptível que o $\mathrm{ka}$ lon teria uma maior abrangência que termos morais, em especial, agathon, a ideia de bem que se encontra nos escritos de filósofos gregos. Como diferentes comentadores apontam, estes termos possuem significados distintos, o que foi afirmado pelo próprio Aristóteles no livro $\mathrm{M}$ da Metafísica (1976, p. 1078b 32-35). Nesta passagem, ele sugere que kalon seria mais abrangente que agathon, pois enquanto este se referiria somente às ações humanas, o primeiro também se referiria a coisas imutáveis ou às que não se movem. Se partirmos do entendimento de Irwin sobre o kalon, poderíamos afirmar que a relação entre kalon e agathon poderia se modificar dependendo das bases do kalon em instâncias es-

\footnotetext{
${ }^{11}$ Aristotle uses kalon both to pick out beauty and to pick out moral rightness, which he recognizes as two distinct properties.

${ }^{12}$ Deve-se notar que Irwin parece defender a sua posição para fundamentar um único ponto, a de que kalon não poderia ser traduzida como "bonito" [beautiful], mas por outros termos, como "admirável" [admirable] ou "belo" [fine].
} 
pecíficas. Essa compreensão seria não somente de Aristóteles, senão que podemos observar um entendimento semelhante, senão igual, em Platão.

A noção de kalon e de agathon seriam intrinsicamente conectados para Platão. De acordo Rachel Barney (2010, p. 363-364), "No Mênon e no Simpósio, a frase 'boas coisas' (ta agatha) é substituída por 'belas coisas' (ta kala) como se as duas fossem equivalentes [...] o belo é algo menos que idêntico ao bom - mas chega perto o suficiente para servir como uma espécie de proxy." ${ }_{13}$ Barney argumenta que essa relação se daria pela definição que Platão daria a kalon e $a$ gathon. Ambos os conceitos diriam respeito acerca da apropriação à função daquilo que é observado (BARNEY, 2010, p. 364-365). Ao realizar a sua função com excelência, a coisa realiza o seu fim com agathon e kalon. Por isso, tudo o que seria agathon também seria kalon, ainda que o inverso pudesse não ser verdadeiro, dado que kalon também seria usado em contextos não funcionais, como o da beleza corporal..$^{14}$

Encontramos um argumento semelhante em Aryeh Kosman (2010, p. 354-356), quando este afirma que o kalon não seria distinto ou uma adição ao agathon, mas o modo como este se apresenta para nós. Saberíamos que algo possui valor moral por apresentar kalon, ou seja, por se apresentar como sendo digno de ser desejado. Ainda que os sentidos de ambos os termos sejam distintos, eles se refeririam à mesma

\footnotetext{
${ }^{13}$ In the Meno and Symposium the phrase "good things" (ta agatha) is substituted for 'fine things' (ta kala) as if the two were equivalent [...] the fine is something less than identical to the good-yet it comes close enough to serve as a kind of proxy.

${ }^{14}$ Nicholas Riegel (2014) apresenta um argumento semelhante ao da Barney.
} 
base. ${ }^{15}$

Porém, demonstrar que há uma relação de identidade, ou algo próximo o suficiente desta, entre kalon e agathon não responde à questão se kalon teria somente um sentido estético ou se há diferentes sentidos de kalon, um estético e outros não estéticos. Caso a resposta de Irwin seja correta, se o sentido de kalon seria estético ou não dependeria da sua base, ainda que a definição de kalon continue sendo a mesma em cada um dos casos. Contrário ao Irwin, as respostas de Barney, Kosman, entre outros, assumem que kalon possui um papel estético mesmo em casos morais, pois este termo concerne mais à aparência daquilo que se apresenta para nós como bom, como agathon, e que nos causaria uma experiência específica, o da admiração. ${ }^{16}$

Embora a relação de identidade entre kalon e agathon seja interessante e pudesse explicar como a beleza moral seria possível, ela possui aspectos que são problemáticos. $\mathrm{O}$ primeiro destes seria o da compatibilidade metafísica da abordagem grega com uma contemporânea. A compreensão de mundo contemporânea é diferente da dos gregos e não seria claro se os conceitos de kalon e agathon seriam aplicáveis ao atual contexto. Um outro problema seria se o kalon causaria as mesmas experiências estéticas que as que investigamos. Assim como a compreensão metafísica da realidade seria distinta entre os diferentes períodos, é plausível que as compreensões sobre estética e experiência estética pudessem

\footnotetext{
${ }^{15}$ Werner Jeager defende uma posição semelhante ao de Kosman (2013, p. 75).

${ }^{16}$ Além do Nicholas Riegel, mencionado na nota 9, outros que defenderam uma interpretação estética de kalon seriam Kelly Rogers (1993), Gabriel Richardson Lear (2006a; 2006b) e Richard Kraut (2013).
} 
ser distintas. Desta forma, a busca de uma resposta para a hipótese da beleza moral através da noção grega de kalon exigiria um extenuante esforço hermenêutico que seja capaz de estabelecer uma comparação entre esta noção e as noções contemporâneas de moralidade e de estética.

Uma outra forma de explicar a relação entre propriedades estéticas e morais seria através da relação de superveniência (MCGINN, 2003, p. 97). O recurso a relações de superveniência para explicar a relação entre propriedades estéticas e morais e como as propriedades estéticas adquirem ao menos parte de suas propriedades não é incomum e se baseia na ideia de que as propriedades estéticas se baseiam e dependem de propriedades físicas, ou, pelo menos, propriedades não físicas como propriedades fenomenais e, talvez, formais (SIBLEY, 2001, p. 35-37; CARROLL, 1999, p. 191-193). Somente que, no caso da beleza moral, a base das propriedades estéticas não seriam propriedades físicas, mas sim propriedades morais.

É muito comum definir a relação de superveniência através da comparação entre objetos. ${ }^{17}$ Para o filósofo Jaegwon Kim (1993a, p. 58), a relação de superveniência pode ser entendida da seguinte forma: "A sobrevém fracamente $B$ se e somente se, necessariamente, para qualquer $x$ e $y$, se $\mathrm{x}$ e y compartilham todas as propriedades de B, então x e y compartilham todas as propriedades de A - isto é, indiscernibilidade em relação a $B$ acarreta indiscernibilidade em relação a A." ${ }^{18}$ Em termos bem simples, uma relação de

\footnotetext{
${ }^{17}$ Para o presente artigo, não há a necessidade de diferenciarmos entre superveniência forte e fraca, embora ela seja relevante em questões mais específicas acerca da superveniência.

${ }^{18} \mathrm{~A}$ weakly supervenes on $\mathrm{B}$ if and only if necessarily for any $\mathrm{x}$ and $\mathrm{y}$ if $\mathrm{x}$ and $\mathrm{y}$ share all properties Cont.
} 
superveniência diz que, quando certas propriedades surgem, outras também surgem. Não há como separá-las. ${ }^{19} \mathrm{O}$ filósofo Jerrold Levinson define a relação de superveniência estética de forma semelhante (2011, p. 135). Contudo, a noção de relação de superveniência não está livre de problemas.

Um problema da pressuposição da existência de uma relação de superveniência entre propriedades morais e propriedades estéticas é que a relação de superveniência não explica realmente o porquê desta relação, somente afirma que ela acontece. Essa relação seria um fato bruto, ou seja, um fato que pressupomos existir, mas que ainda não possuímos uma explicação para a sua existência, ou que não permite uma explicação. (BARNES, 1994, p. 61-62). Encontramos nela somente uma descrição de como o mundo seria estruturado, mas sem alguma explicação do porquê essa estruturação se deu. Kim reconhece este problema (1993b, p. 159) e diz que: "Na ausência de correlações psicofísicas específicas, e de algum conhecimento delas, tal alegação de superveniência deveria nos parecer um mero artigo de fé seriamente carente de motivação tanto evidencial quanto explicitamente.” ${ }^{2021}$. Assim, embora a relação de

in $\mathrm{B}$ then $\mathrm{x}$ and $\mathrm{y}$ share all properties in $\mathrm{A}$ - that is, indiscernibility with respect to $\mathrm{B}$ entails indiscernibility with respect to A.

${ }^{19}$ Deve-se notar que a relação de superveniência não reduz uma propriedade a outra, no caso, uma não é capaz de explicar a outra e tampouco conecta conceitualmente as propriedades, de forma que falar de uma implicaria falar da outra.

${ }^{20}$ In the absence of specific psychophysical correlations, and some knowledge of them, such a supervenience claim should strike us as a mere article of faith seriously lacking in motivation both evidentially and explanatorily

${ }^{21}$ No entanto, Kim ainda argumenta que a simples determinação empírica da existência de uma relação de superveniência entre dois tipos distintos de propriedades, ao menos em alguns casos, como das propriedades mentais sobre as físicas, já serviria de uma base evidencial para afirmarmos, ao menos, que ela existiria sem a necessidade de argumentos posteriores. 
superveniência nos ofereça uma resposta à questão acerca do tipo de conexão entre propriedades estéticas e propriedades morais, ela não explica o porquê desta relação, somente afirma que ela existe.

Contudo, não é claro que esta relação de superveniência entre propriedades morais e estéticas realmente exista, pois ela poderia ser um erro categorial, como visto acima. $\mathrm{O}$ argumento do porquê de sua existência é mais do que uma simples explicação, ela é, em primeiro lugar, um motivo para acreditarmos que essa relação exista. No fim, o argumento da superveniência seria incompleto, pois ele necessita de uma explicação de como esta relação veio a ser para estarmos justificados em afirmar que ela seria real.

Dadas as possíveis dificuldades das relações de identidade e superveniência, outra possibilidade de tentar explicar a beleza moral seria através da noção de causalidade. A postulação de relações causais é comum na experiência estética. Temos uma experiência estética por certas propriedades a causarem em nós. Porém, há diferentes compreensões de quais propriedades nos causariam essas experiências estéticas.

Por um lado, há quem defenda que as propriedades estéticas seriam causalmente eficazes e nos causariam experiências estéticas. É muito comum entre os proponentes deste campo serem realistas no que diz respeito às propriedades estéticas, pois, visto que as propriedades estéticas seriam causalmente eficazes, elas teriam que ser propriedades reais, caso contrário, não apresentariam eficácia causal (CARROLL, 1999, p. 189-200; 2010a, p. 103-104; LEVINSON, 2006, p. 338-350). Por outro lado, há quem 
defenda que as propriedades capazes de nos causar experiências estéticas seriam as não estéticas. Tal interpretação é defendida, normalmente, por antirrealistas, pois eles pressupõem que as propriedades estéticas não seriam propriedades reais, mas sim uma forma de falar sobre os objetos a partir de nossas percepções acerca deles (GOLDMAN, 1993). ${ }^{22}$

Além da clara discordância sobre o estatuto ontológico das propriedades estéticas, uma das diferenças mais relevantes entre os realistas e os antirrealistas seria acerca das bases das propriedades estéticas. Os realistas não possuem explicações que são capazes de responder como as propriedades estéticas se dão no mundo. Eles argumentam de forma indireta, apoiando-se, muitas vezes, na ideia de que a experiência estética somente seria possível caso as propriedades estéticas fossem reais. No máximo, eles afirmam que essas propriedades seriam emergentes das propriedades não estéticas, e que seriam submetidas a uma relação de superveniência com estas (SIBLEY, 2001, p. 35-37; LEVINSON, 2006, p. 342-343; 2011; CARROLL, 2010a, p. 101).

Por sua vez, posto que os antirrealistas afirmam que as propriedades estéticas não seriam reais, eles defendem que podemos falar sobre elas por termos experiências reais delas (GOLDMAN, 1995, p. 18-26). Nesse sentido, as nossas experiências estéticas são o que definiriam a nossa fala sobre propriedades estéticas. Ademais, como observado acima, os antirrealistas afirmam que as nossas experiências estéticas

\footnotetext{
${ }^{22}$ Há diferenças entre os antirrealistas acerca de como atribuiríamos propriedades estéticas aos objetos que percebemos. Mas a análise de cada uma dessas diferenças não é relevante para o presente artigo, somente a posição proposta por Hume, que será investigada a seguir.
} 
seriam causadas pelas propriedades não estéticas dos objetos percebidos (GOLDMAN, 1995, p. 39-44). Seria plausível, portanto, afirmarmos que as propriedades estéticas seriam causadas por propriedades não estéticas.

Supondo ambos os tipos de abordagem, vemos que há, ao menos, duas formas de explicar como as propriedades morais e estéticas poderiam ter uma relação causal: (i) as propriedades morais causam as propriedades estéticas; ou (ii) há uma causa comum das propriedades morais e estéticas, de forma que, se temos uma propriedade moral, temos, conjuntamente, uma propriedade estética.

Embora ambas as propostas causais da beleza moral possam exibir similaridades acerca da abordagem estética, e, assim, não há impedimento algum para que elas adotem os mesmo conceitos estéticos, há uma diferença importante no que diz respeito ao tipo de teoria moral que poderá ser adotada por cada proposta, em especial, no quesito metaético. A que afirma que existe uma causa comum entre as propriedades morais e as estéticas possuem uma latitude no tipo de teoria moral que pode ser defendido. Os proponentes dessa proposta podem defender desde teorias morais realistas até antirrealistas, pois eles não precisam se comprometer com uma concepção realista das propriedades morais. Propriedades morais podem ser consideradas como uma expressão e não uma qualidade encontrada no mundo (BLACKBURN, 1998, p. 50/80). Ao permitir a adoção de teorias morais antirrealistas, que defendem que as propriedades morais não se encontrariam no mundo, mas que seriam, no máximo, projeções realizadas pelo agente moral, não haveria a necessidade de defender que essas proprieda- 
des sejam causalmente eficazes. Outro ponto desta proposta seria que ela permitiria que propriedades não estéticas possam configurar como parte do explanans da relação causal entre as propriedades morais e estéticas.

Por outro lado, a outra proposta causal, por afirmar que as propriedades morais causariam as estéticas, tem uma restrição acerca do tipo de teoria moral que pode ser adotado, pois ela teria que pressupor que as propriedades morais sejam causalmente eficazes. Para que as propriedades morais possam ser causalmente eficazes, elas devem ser reais, caso contrário, não poderia existir uma relação causal entre ambos os tipos de propriedades. Tal proposta tem que pressupor que propriedades morais sejam verdadeiras, e, por isso, somente teorias morais realistas seriam aceitáveis para essa concepção causal da beleza moral.

Uma das propostas mais interessantes que afirma existir uma causa comum das propriedades morais e estéticas é a do filósofo David Hume. A hipótese defendida neste artigo é de que uma abordagem humeana da moralidade e da estética seria capaz de prover uma explicação para a noção beleza moral e tornar a sua hipótese extremamente plausível. De acordo com a concepção humeana da natureza humana e dos valores, tanto morais quanto estéticos, a participação de agentes morais e observadores em um evento moral envolve experiências que possuem uma estrutura e mecanismo semelhante aos das experiencias estéticas. Assim, certos eventos aos quais propriedades morais são atribuídas seriam capazes de causar experiências estéticas em observadores, que atribuiriam, então, beleza a esses eventos.

Faz-se também necessário investigar se há uma abordagem da experiencia estética compatível com a teoria moral e 
estética humeana. Assim, antes que discorramos sobre a teoria moral e estética de Hume, a noção de experiência estética será investigada, visto a sua centralidade para a hipótese da beleza moral.

Antes de prosseguirmos, deve ser destacado que o escopo da presente investigação seria o de investigar somente como certos eventos ou atos adquirem propriedades estéticas em virtude de possuírem propriedades morais, ou como podemos atribuir propriedades estéticas a certos atos ou eventos morais. No entanto, o contrário não será investigado, no caso, se poderíamos, igualmente, atribuir propriedades morais a certos atos ou eventos que possuíssem propriedades estéticas. Neste caso, as propriedades morais se dariam em virtude das propriedades estéticas. Além disso, não deve ser compreendido que qualquer evento moral apresentaria propriedades estéticas. Do fato de que alguns eventos morais possuam beleza moral não significa que todos a possuiriam.

\section{DUAS CONCEPÇÕES DA EXPERIÊNCIA ESTÉTICA}

Em termos simples, a experiência estética seria o instante em que as propriedades estéticas de um objeto ou evento se apresentariam para nós. Normalmente, adquirimos as bases para realizar o julgamento estético e determinar o valor estético do objeto percebido a partir desta experiência. ${ }^{23}$ Esta

\footnotetext{
${ }^{23}$ Dizemos 'normalmente' por a experiência estética não ser o único caminho pelo qual poderíamos realizar juízos estéticos, em especial, quando lidamos com obras de arte. Essa é a questão do "testemunho". Há aqueles que defendem que o juízo estético somente poderia se basear na experiência estética, o que exigiria um contato direto, ou da memória de um contato direto, do objeto ou evento que teria propriedades estéticas (STOLNITZ, 1960, p. 52-60). Mas, contrariamente, há Cont.
} 
definição simples é, claramente, insuficiente, visto que ela deixa de lado a questão de que estes outros termos, propriedade, julgamento e valor estético, exigem uma fundamentação própria.

Muito utilizados em análises estéticas, estes termos seriam fortemente conectados, ainda que não possuíssem uma interrelação conceitual. Ademais, como eles se relacionam depende muito de como entendemos a noção de experiência estética, que parece, em alguns momentos, condicionar o que as propriedades estéticas seriam, que tipo de julgamento estético seria possível e, com isso, como o valor estético de um evento ou objeto seria determinado (BEARDSLEY, 1982a). Assim, diferentes concepções destes conceitos estéticos tornam-se possíveis conforme a compreensão de cada um e de acordo com a sua relação com os demais.

Devemos alertar que, embora relevante na nossa prática de atribuição de beleza a objetos e eventos, a experiência estética poderia ser irrelevante para a apreciação de obras de arte, ainda que a apreciação estética destas possa, em diferentes ocasiões, acrescentar uma diferente dimensão a elas (CARROLL, 1999, p. 174-182; KORSMEYER, 1977). Por um lado, a experiência estética não seria condição suficiente para a definição de obra de arte. Caso fosse, eventos e objetos encontrados na natureza que nos proporcionam experiências estéticas seriam obras de arte. Tampouco seria a experiência estética condição necessária para um objeto ser

também quem defenda que um juízo estético seria possível, em alguns casos, sem o contato direto com o objeto ou evento com propriedades estéticas, mas somente através de um conhecimento proposicional adquirido de alguém que já teve esse contato direto (LEVINSON, 2006, p. 338; MESKIN, 2004). 
uma obra de arte. Fosse assim, objetos que são considerados obras de arte nos dias de hoje não seriam, realmente, arte, como os que visam despertar não uma experiência estética, mas sim questionamentos sociais, políticos e, até mesmo, sobre o próprio conceito de arte. Sobre esse ponto, Jerome Stolnitz (1960, p. 39-40) afirma que:

A melhor evidência dessa visão mais ampla é encontrada nas artes. Pois temos aqui registros permanentes dos objetos que despertaram interesse estético. Também pode ser encontrada, no entanto, na apreciação da natureza. Os temas escolhidos da natureza para tratamento pelos artistas mostram a expansão do interesse perceptivo. [...] Se nos limitarmos à arte dos últimos 150 anos, encontraremos uma enorme quantidade de arte dedicada a dois tipos de objetos que o "senso comum" considera intrinsecamente não estéticos, a saber, objetos cotidianos e coisas e eventos feios ou grotescos..$^{24}$

Desta forma, não somente seria possível separarmos estética da arte, como seria, até mesmo, desejável, caso contrário, não poderíamos explicar as nossas relações com a atribuição de beleza a eventos e objetos cotidianos, incluindo indivíduos. A investigação sobre os fundamentos da experiência estética não se relaciona conceitualmente com os fundamentos da arte. ${ }^{25}$ Com isso, podemos deixar de lado a investigação acerca das bases do conceito de arte, e investi-

\footnotetext{
${ }^{24}$ The best evidence of this broadening of vision is to be found in the arts. For here we have permanent records of the objects which have aroused aesthetic interest. It can also be found, however, in the appreciation of nature. The subjects chosen from nature for treatment by artists show the expansion of perceptual interest. [...] If we confine ourselves to the art of the last 150 years, we find an enormous amount of art devoted to the two sorts of objects which "common sense" considers intrinsically unaesthetic, viz., dull, commonplace objects and ugly or grotesque things and events.

${ }^{25}$ Dizemos conceitualmente para acentuar o fato de que, mesmo que o conceito de estética não possua uma relação semântica com o conceito de arte, não seria necessário entender o que a arte é para entendermos o conceito de estética, ou ainda não seria necessário o uso deste para o entendimento do conceito de arte.
} 
gar diretamente o conceito de experiência estética.

$\mathrm{O}$ conceito contemporâneo de experiência estética tem uma história mais longa que o próprio conceito de estética e teria a sua raiz com o filósofo inglês Anthony Ashley Cooper, mais conhecido como Lord Shaftesbury, e que influenciou a geração subsequente do empirismo britânico, em especial, Francis Hutcheson e David Hume (DICKIE, 1973; TOWNSEND, 1987; CARROLL, 2010b, p. 119-121). Há, claramente, diferenças em suas teorias estéticas. Porém, há, também, diversas similaridades entre suas teorias. Em especial, suas concepções acerca da experiência estética possuem, ao menos, três aspectos extremamente relevantes, aspectos estes que influenciaram as gerações de estetas subsequentes, em especial, os chamados teóricos da atitude estética. ${ }^{26}$ Esses três aspectos são: o do desinteresse, da imediação, e o de unidade (ou completude) (BEARDSLEY, 1982b, p. 82-87; 1982c; TOWNSEND, 1987, p. 289-300; SHELLEY, 2017; MITIAS, 1982; STOLNITZ, 1961).

$\mathrm{O}$ elemento de desinteresse caracteriza o fato de que, em uma experiência estética, uma pessoa aborda o objeto ou evento sem qualquer propósito ulterior. Diversos filósofos apontaram para o fato de que nossos julgamentos estéticos e a atribuição de beleza a um evento ou objeto somente poderiam ser considerados realmente estéticos se estes fossem abordados sem qualquer motivação além da percepção do próprio objeto. Se, ao observar um famoso quadro, uma pessoa tiver, p.ex., o objetivo de analisá-lo com fins de construir um trabalho universitário, dificilmente esta pessoa ob-

\footnotetext{
${ }^{26}$ Entre os filósofos considerados como os mais importantes proponentes da atitude estética se encontram: Arthur Schopenhauer, Jerome Stolnitz, e o Monroe C. Beardsley.
} 
servará este quadro sem qualquer outro motivo que a própria apreciação estética. A experiência estética exigiria um distanciamento dos próprios objetivos e uma completa atenção sobre o objeto contemplado. O filósofo Jerome Stolnitz, um dos maiores proponentes da ideia de atitude estética, afirmou (1960, p. 35) que:

A primeira palavra, "desinteressado" [...] significa que não olhamos para o objeto com a preocupação de qualquer outro propósito ao qual ele possa servir. Não estamos tentando usar ou manipular o objeto. Não há propósito algum governando a experiência além do propósito de apenas ter a experiência. Nosso interesse repousa sobre o objeto sozinho. ${ }^{27}$

Além disso, o desinteresse exige, também, um distanciamento das crenças e das emoções relevantes que o observador pudesse ter. Esse ponto não deve ser compreendido como uma espécie de "véu da ignorância estético", mas somente uma posição simpática frente à obra de arte, o que alguns filósofos poderiam chamar de uma espécie de princípio da caridade estético. ${ }^{28}$ Os preconceitos, especialmente os morais, e as emoções imediatas frutos desses preconceitos impedem que o observador possa ter uma completa apreciação estética daquilo que se encontra em sua frente.

Para Stolnitz, a simpatia frente ao objeto ou evento deveria ser considerada um aspecto da atitude estética diferen-

\footnotetext{
${ }^{27}$ The first word, "disinterested" [...] means that we do not look at the object out of concern for any ulterior purpose which it may serve. We are not trying to use or manipulate the object. There is no purpose governing the experience other than the purpose of just having the experience. Our interest comes to rest upon the object alone.

${ }^{28} \mathrm{O}$ termo "obra de arte" é utilizado nesta parte meramente como uma referência segura de um objeto que poderia, em diversos momentos, nos causar essa experiência estética. Mas esse termo poderia ser facilmente substituído pelo termo "objetos estéticos", entre outros.
} 
te do desinteresse. Contudo, há estetas que defenderam que essa postura simpática seria somente mais uma faceta do desinteresse. Levinson diz que o desinteresse: "deve ser entendido em termos de um desligamento ou distanciamento temporário das preocupações e emoções estritamente pessoais, deixando-as de lado no que diz respeito de lidar ou agir sobre elas, de modo a permitir atenção total ao objeto que está sendo experienciado [...]" ${ }^{29}$ (LEVINSON, 2016, p. 30)

Por sua vez, o aspecto de imediação diz respeito à forma de como a experiência estética seria recebida do objeto observado. Porém, a imediação pode ser compreendida de, ao menos, duas formas diferentes, mas excludentes. A primeira forma diz respeito de como a obra de arte se apresenta para nós. Nesse sentido de imediação, a experiência estética se dá diretamente com a percepção da obra de arte (STOLNITZ, 1960, p. 58-66). Ao observarmos a obra de arte, temos um acesso direto ao seu valor estético. Por outro lado, a imediação também diz respeito ao fato de que a experiência estética não seria mediada por qualquer tipo de consideração cognitiva ou afetiva (SHELLEY, 2017). A experiência estética da obra de arte somente se daria caso não houvesse pressuposição alguma de um conhecimento ou emoção para a apreensão do seu valor estético.

Em ambos os sentidos de imediação, a experiência estética se refere à percepção da obra de arte sem qualquer mediação. $\mathrm{O}$ observador tem que lidar somente com o

\footnotetext{
${ }^{29}[. .$.$] should be understood in terms of a temporary detaching or distancing of one's narrowly per-$ sonal concerns and emotions, sidelining them as regards addressing or acting on them, so as to allow full attention to the object being experienced [...]
} 
fenômeno da obra de arte da sua experiência. As propriedades estéticas assim como o valor estético das obras de arte são determinadas a partir das qualidades deste fenômeno, mais especificamente, as propriedades estéticas se dão pelas qualidades objetivas da obra de arte, e o seu valor estético seria uma resposta imediata a essas propriedades.

Porém, essa relação imediata com a obra de arte não significa que ela deva ocorrer instantaneamente. Nessa imediação seria exigido, somente, que o observador se relacione diretamente com a obra, pois o seu valor se encontra ali, na contemplação (BEARDSLEY, 1982c, p. 288-289). Não seria necessário que a experiência estética seja uma apreensão instantânea e em um único momento. Na verdade, ela poderia se dar por um longo período ou em diferentes momentos de contemplação. Enquanto a beleza de um evento ou objeto poderia ser apreendida em um único instante em certos casos, há outros em que quanto mais contemplamos uma obra de arte, mais profunda a nossa apreciação estética poderia se tornar. Ademais, ainda que a experiência estética não deva ser mediada por algum tipo de conhecimento, isso não faz com que não fosse necessário que condições específicas, inclusive cognitivas e epistêmicas, devam ser preenchidas para que experiências estéticas sejam possíveis, ou, ainda, para que se tornem ainda melhores. Há uma grande diferença qualitativa na apreciação estética de obras de arte entre adolescentes e estudantes de arte ou da história da arte, p.ex., e essa diferença é devida ao conhecimento aprofundado sobre a arte e mesmo sobre a vida humana, sociedade, etc.

Finalmente, a unidade da experiência estética seria a ne- 
cessidade da compreensão da obra de arte como um todo, de forma que tenhamos um acesso adequado ao seu valor estético. ${ }^{30}$ Embora o emprego da noção de necessidade pareça estranho, visto introduzir uma modalidade na experiência estética, e, assim, uma certa normatividade em um evento mental, há, realmente, uma compreensão atitudinal da unidade da experiência estética, no caso, como a experiencia estética deveria ser. Há uma grande diferença na apreciação estética entre os indivíduos que observam a obra por completo e os que observam somente alguns aspectos da mesma. Mesmo críticos de arte apresentariam diferenças qualitativas em seus julgamentos caso apreciassem somente partes discretas das obras de arte. A unidade da experiência estética deve exibir, então, uma coerência interna da obra de arte (BEARDSLEY, 1982c, p. 292-294). Caso contrário, esta perde a sua integridade e se torna vários pedaços que podem não estabelecer uma conexão entre si e, ao invés de possuir uma única experiência estética, mesmo que temporalmente extensa, o observador terá diferentes experiências estéticas discretas, uma de cada parte da obra.

Por a experiência estética possuir uma espécie de normatividade inerente para a constituição da coerência da obra de arte, poderia ser pensado que a experiência estética deveria ser concebida como o resultado de uma atitude estética (STOLNITZ, 1960, p. 34-39; BEARDSLEY, 1982a, p. 19-21). Essas características, em especial, a da unidade da

\footnotetext{
${ }^{30}$ Esse aspecto foi denominado de diferentes formas, como "completude" e "coerência". Embora possamos, realmente, substituir o termo "unidade" pelo termo "completude", acreditamos que, ainda que possa indicar essa ideia de unidade, o termo "coerência" seria melhor empregado como uma característica das obras de arte que produz a sua unidade.
} 
experiência estética, fizeram com que diferentes teóricos defendessem que a apreciação estética fosse, realmente, uma atitude, um ponto de vista específico que o observador deve tomar. Mesmo que essa leitura acerca da experiência estética seja legítima, há uma outra compreensão possível que mantêm o caráter ativo da experiência estética sem que tenhamos que defender que ela seria uma atividade.

Levinson defende que poderíamos compreender a atitude estética como um tipo de disposição, e não como uma atividade. Com essa nova compreensão da atitude estética, adquirimos uma possibilidade de interpretarmos essa atitude como reativa e não como uma atividade que deva ser realizada. A atitude continuaria como uma espécie de ação nesta interpretação, mas não uma que deva ser realizada conscientemente, senão que ela seria ativada quando a obra de arte se apresenta para o observador, uma resposta frente à obra de arte.

[...] a atitude estética não é tanto uma atividade mental quanto uma disposição para se engajar em tais atividades [...] A atitude estética é uma questão de estar disposto a atender, perceber, responder ou vivenciar de uma determinada maneira; não é em si uma espécie de atenção, percepção, reação ou experiência. ${ }^{31}$ (LEVINSON, 2016, p. 30)

Carroll (2010a, p. 79-85; 1999, p. 170-173) propõe chamar a concepção que apresentaria os três aspectos acima e o da atitude estética como disposição de abordagem orien-

\footnotetext{
${ }^{31}[. .$.$] the aesthetic attitude is not so much a mental activity as a disposition to engage in particular$ such activities [...] The aesthetic attitude is a matter of being disposed to attend, perceive, respond, or experience in a certain manner; it is not itself as such a kind of attending or perceiving or responding or experiencing.
} 
tada ao afeto [affect-oriented approach]. De acordo com ele, essa concepção seria marcada por esses aspectos e por outro ainda mais importante, a saber, o do prazer estético. Essa abordagem postula que há um tipo de sentimento específico da experiência estética que se apresentaria quando o observador se deparasse corretamente com o objeto, ou seja, quando a sua apreciação estética fosse desinteressada, imediada, e apresentasse uma unidade da obra. Esse sentimento que surge através da correta contemplação da obra de arte seria o prazer estético. Para esta abordagem, a experiência estética seria definida por esse tipo específico de prazer.

Propriedades estéticas não seriam propriedades reais, mas somente atribuições ou projeções aos objetos que nos causariam esse prazer (CARROLL, 1999, p. 192-200). Somente encontraríamos propriedades naturais nas obras de arte às quais apreciamos, e seriam essas propriedades que teriam as capacidade de nos causar prazer estético (MOTHERSILL, 1984, p. 335-366; GOLDMAN, 1995, p. 175-176). Os proponentes dessa abordagem defendem que seria mais econômico ontologicamente e mais simples epistemologicamente não pressupor que propriedades estéticas existiriam. Afinal, com a postulação de que seriam propriedades estéticas que nos causariam esse tipo de prazer, haveria a necessidade de comprovar como essas propriedades existiriam. Essa abordagem orientada ao afeto seria, assim, antirrealista.

Entretanto, Carrol critica essa compreensão da experiência estética, em especial, por ter essa noção de prazer esté- 
tico como central e mesmo definidora dessa concepção. ${ }^{32}$ Haveria, ao menos, três problemas com a centralidade desse prazer (CARROLL, 2010a, p. 79-81). O primeiro consistiria no fato de que, em inúmeros casos, as obras de arte não seriam marcadas por qualquer tipo de sentimento por parte do observador. Nesses casos, a apreciação estética simplesmente perpassaria pelas características da obra de arte, e o observador seria capaz de proferir um juízo estético informado, ainda que não existisse qualquer sentimento causado por essa apreciação. Além disso, mesmo quando obras de arte causassem sentimentos em nossas experiências estéticas ao as apreciarmos, isso não significaria que esses sentimentos seriam somente sentimentos de prazer. É bem comum que certas obras de arte nos deixem espantado, ou indignados, ou contemplativos. A busca de reinterpretar esses sentimentos como uma espécie de prazer, ou que eles, ainda assim, gerariam um tipo de prazer seria, além de misterioso, pois não saberíamos que novo tipo de prazer seria esse, uma estratégia ad hoc.

Mas, a nosso ver, a crítica mais interessante e relevante colocada por Carroll seria a de que a imputação da centralidade do prazer ao conceito de experiência estética tornaria este conceito valorativo por definição. Nesse sentido, a experiência estética seria uma aprovação dos eventos e objetos capazes de causá-lo, e ela seria um juízo normativo ou de preferência. Entretanto, a experiência e o julgamento estético não pareceriam envolver um tipo de prazer ou de aprovação do objeto ou evento observado, mas sim a apreensão

\footnotetext{
${ }^{32}$ Carroll ainda aponta que as três características possuem problemas e que poderiam ser criticadas e, até mesmo, abandonadas, caso não possam ser reformuladas.
} 
das suas propriedades estéticas e um juízo descritivo.

Na medida em que o prazer é considerado, prima facie, bom, estipular que o prazer é uma condição necessária da experiência estética torna o conceito de experiência estética um conceito elogioso; a experiência estética nesta visão seria valiosa por definição. No entanto, a experiência estética é indiscutivelmente um conceito descritivo atendendo à forma de uma obra de arte, seja ela prazerosa ou valiosa ou não, é ostensivamente uma experiência estética. [...] Portanto, o uso elogioso do conceito não é seu uso primário; o uso descritivo parece ser mais fundamental. ${ }^{33}$ (CARROLL, 2010a, p. 80)

Ainda que pudéssemos identificar na obra de arte alguma propriedade que nos causasse prazer, isso seria contingente, pois ela não seria nem necessária ou suficiente para que a experiência estética acontecesse (CARROLL, 1999, p. 180). Carroll chega, então, à conclusão de que o mais interessante para a estética seria deixar de lado essa concepção de experiência estética e adotar uma outra que possa comportar suas observações. Ele propõe, assim, a $a$ bordagem orientada pelo conteúdo [content-oriented approach] (2010a, p. 101-106; 1999, p. 168-170).

Como o próprio nome diz, essa abordagem afirma que a experiência estética se caracteriza por um conteúdo específico. A experiência pode ser chamada, efetivamente, de estética, e não moral ou religiosa, em virtude de o seu conteúdo ser estético. A diferença da abordagem orientada ao afeto é que a experiência estética se caracterizaria por um

\footnotetext{
${ }^{33}$ To the extent that pleasure is regarded as prima facie good, to stipulate that pleasure is a necessary condition of aesthetic experience makes the concept of aesthetic experience a commendatory concept; aesthetic experience in this view would be valuable by definition. However, aesthetic experience is arguably a descriptive concept-attending to the form of an artwork, whether it is pleasurable or valuable or not, is ostensibly an aesthetic experience. [...] So the commendatory use of the concept is not its primary use; the descriptive usage would appear to be more fundamental.
} 
prazer específico, enquanto na abordagem orientada pelo conteúdo, o conteúdo cognitivamente apreendido seria estético. A questão se torna, então, definir o que seria esse conteúdo estético. Carroll menciona que encontramos na tradição, ao menos, a forma da obra de arte e propriedades estéticas como parte deste conteúdo (2010a, p. 103). ${ }^{34}$

A forma da obra de arte lembra, em vários aspectos, a noção de unidade da experiência estética, que exige que a obra seja coerente consigo mesma. Há uma ordem interna à obra de arte, uma organização que a faz ser como ela é. A experiência estética seguiria essa ordem interna, reconstruindo a organização da obra de arte. Através dessa reconstrução, as propriedades estéticas surgiriam e se alinhariam de acordo com a ordem que configura a obra. Por sua vez, há diferentes tipos de propriedades estéticas, e dentre as categorias mais relevantes estariam a das propriedades sensoriais, como espessura e unidade das cores, etc., e a das propriedades expressivas, ou seja, as características que parecem expressar um tipo de sentimento, como tristeza, alegria, etc. ${ }^{35}$

De acordo com esta abordagem, a experiência estética teria seu início com a atenção dada pelo observador para a obra de arte. Essa atenção revela na obra uma série de relações formais da sua unidade e, se for o caso, diferentes pro-

\footnotetext{
${ }^{34}$ Carroll afirma que esse conteúdo apontado por ele deve ser visto como um mínimo, e poderiam existir outros tipos de conteúdo da experiência estética. Esses somente teriam sido os mais comuns na tradição.

${ }^{35}$ Em sua introdução à filosofia da arte, Carroll diz que a experiência estética na abordagem orientada pelo conteúdo se concentraria na unidade, diversidade, e intensidade de uma obra de arte. Porém, a diversidade e a intensidade seriam nada mais do que as relações quantitativas e qualitativas das propriedades estéticas, no caso, quantas propriedades estéticas existiriam na obra de arte e o quão forte cada uma delas seria.
} 
priedades estéticas. $O$ julgamento estético seria, de certa forma, apenas a expressão daquilo que se apresentaria para nós. Ao afirmarmos que um objeto $O$ teria uma beleza $b$, a princípio, esse julgamento se assemelharia a uma simples descrição, de que seria verdadeiro que $O$ possuiria $b$. Tal compreensão da apreciação estética coloca a experiência estética como representacional, pois as propriedades atribuídas ao objeto são realmente do objeto e não uma projeção de estados afetivos do observador ao objeto, e o juízo estético como um juízo cognitivo, ou seja, capaz de ser correto ou errôneo a partir dos valores de verdade na relação frasemundo.

Carroll defende, contudo, que, ainda que essas propriedades estéticas sejam reais, elas teriam uma qualidade ontológica diferente de outras que encontramos na natureza, no caso, elas seriam dependentes de resposta [response-dependent] (1999, p. 191-195; 2010a, p. 103-104), ou seja, elas surgem ou, até mesmo, existem somente para seres que possuam as capacidades cognitivas e/ou afetivas necessárias para tanto. Ele continua e afirma que essa qualidade seria um tipo de disposição de criar certas impressões ou efeitos nos seres que tenham estas capacidades. Contudo, elas não seriam redutíveis a essas capacidades, ou seja, elas não seriam uma criação subjetiva dos observadores, e, também, não seriam redutiveis às propriedades naturais ou históricas das quais elas dependem. Elas seriam propriedades emergentes destas propriedades naturais ou históricas, e, por isso, possuiriam um estatuto ontológico próprio. Essa abordagem seria realista, visto que propriedades estéticas seriam reais, e não uma projeção ou uma mera forma de falar. Elas seriam detectáveis 
nas propriedades naturais ou históricas, mas não redutíveis a estas.

Podemos, agora, nos perguntar: qual dessas duas abordagens seria a melhor para caracterizar a atribuição de beleza a eventos morais? Acreditamos que, apesar de ambas as abordagens tenham problemas específicos, a abordagem orientada ao afeto apresenta soluções mais econômicas e questões menos complexas do que a outra abordagem.

Em primeiro lugar, a abordagem orientada pelo conteúdo parte do pressuposto de que a afirmação de que um objeto possui propriedades estéticas não se diferenciaria da afirmação de que objetos teriam peso, altura, extensão, etc. Por isso, a afirmação de que um objeto ou evento possuiria beleza seria, aparentemente, descritiva, pois ela seria a afirmação da existência de uma propriedade específica no objeto em questão. Entretanto, embora pareça que, quando fazemos julgamentos estéticos, realizamos um único julgamento, um de natureza descritiva, fazemos, na verdade, dois julgamentos ao mesmo instante.

Ao afirmarmos, p.ex., que "o pôr do sol de ontem foi esplêndido" ou "essa caneta é feia" não somente atribuímos uma suposta propriedade estética a um evento natural ou a um objeto mundano, mas também realizamos um juízo valorativo, como o do fato da caneta ser feia ou que o pôr do sol foi esplêndido. Assim, além das propriedades físicas atribuídas tanto a caneta quanto ao pôr de sol, dizemos que elas possuiriam também propriedades estéticas, um tipo de propriedade que não podemos explicar através das ciências 
da natureza. ${ }^{36}$

Mas, ao atribuirmos propriedades estéticas a um evento ou objeto, não afirmamos simplesmente que ele possui propriedades estéticas, mas informamos a sua beleza, no caso, a qualidade específica dessa propriedade estética. Nos casos acima, a qualidade de ser feio foi atribuída à caneta assim como a qualidade de ser esplêndido ao pôr do sol. Esse tipo de julgamento seria igualmente valorativo, pois ele determina a qualidade da propriedade estética dos objetos e eventos a partir de nossas considerações sobre eles. Ele seria semelhante aos julgamentos que realizamos das propriedades físicas dos objetos e eventos, ao afirmarmos que eles seriam grandes ou pequenos. Estes julgamentos das propriedades físicas dos objetos são qualitativos, e têm uma grande conexão com outros aspectos além dos físicos, como o contexto cultural de quem pronuncia tal julgamento. $\mathrm{O}$ filósofo Alan Goldman exprime a mesma ideia (1990, p. 23) ao afirmar que:

Dizer que um objeto é bonito ou feio é, aparentemente, referir-se a uma propriedade do objeto. Mas é também expressar uma resposta positiva ou negativa a ele, um conjunto de valores estéticos, e sugerir que outros deveriam responder da mesma maneira. Esses julgamentos são descritivos, expressivos e normativos ou prescritivos ao mesmo tempo. ${ }^{37}$

\footnotetext{
${ }^{36}$ Deve-se ter em mente que a afirmação "não encontramos propriedades estéticas no mundo físico" seria uma petição de princípios, pois já pressupõe a posição que deveríamos comprovar. No entanto, dizer que as ciências da natureza não conseguem explicar as propriedades estéticas é, somente, o reconhecimento de que, ao menos atualmente, elas não possuem qualquer explicação para a nossa prática estética.

${ }^{37}$ To say that an object is beautiful or ugly is seemingly to refer to a property of the object. But it is also to express a positive or negative response to it, a set of aesthetic values, and to suggest that others ought to respond in the same way. Such judgments are descriptive, expressive, and normative or prescriptive at once.
} 
Embora Carroll tenha criticado a abordagem orientada ao afeto, afirmando que, nesse contexto, a experiência estética seria valorativa por definição, ele não poderia negar que um julgamento estético tenha um conteúdo valorativo. Além do mais, se disséssemos que uma obra de arte exibisse certas propriedades estéticas, e que essas seriam propriedades pertencentes ao objeto, como a abordagem orientada pelo conteúdo defende, ainda não poderia ser negado que esse julgamento seria valorativo, pois o observador expressaria a sua relação com aquele objeto, influenciando outros a estabelecerem a mesma relação. Há uma normatividade inerente no julgamento estético que Carroll desconsidera.

Também deve ser notado que ele parece cometer um erro categorial, pois o fato de experenciarmos algo como prazeroso não teria como ser valorativo, pois somente julgamentos poderiam exibir essa qualidade. Experiências são relações fenomenológicas com o mundo, e não a afirmação de que algo seria verdadeiro ou falso, bom ou mal, ou ainda prazeroso ou não. Assim, não faz sentido afirmar que a experiência estética proposta pela abordagem orientada ao afeto teria um conteúdo valorativo por definição, pois, por um lado, além das experiências de objetos físicos serem, da mesma forma, valorativos por definição, por outro lado, somente julgamentos podem ser valorativos ou não.

Há, ainda, o desafio colocado por Carroll contra a hipótese da beleza moral, de que esta não seria plausível por a beleza ser somente atribuída a objetos sensíveis e que, portanto, a existência de uma beleza moral não seria possível. De certa forma, ambas as abordagens serviriam para a hipótese da beleza moral, visto que nenhuma das duas negam que propriedades estéticas poderiam se basear em proprie- 
dades morais de eventos morais. Porém, elas possuem características diferentes e dependem de como observamos a relação entre as propriedades estéticas e as morais.

Como visto acima, a abordagem orientada pelo conteúdo pressupõe uma relação de superveniência entre propriedades estéticas e não estéticas. Podemos seguir essa noção e afirmar que, de acordo com essa abordagem, as propriedades estéticas sobreviriam às morais. Entretanto, como visto acima, a noção de relação de superveniência introduz mais problemas que respostas. Ademais, antes que essa relação seja pressuposta, teríamos que demonstrar como as propriedades morais seriam, de fato, propriedades reais, pois o próprio Carroll acredita que propriedades estéticas somente poderiam sobrevir às não estéticas caso alguma destas fosse perceptivel pelos cinco sentidos. Isso introduziria ainda mais problemas para a hipótese da beleza moral se a considerarmos pela abordagem orientada pelo conteúdo.

Há dois caminhos para enfrentarmos o problema colocado por Carroll. O primeiro seria negar que a beleza seria somente aplicável a objetos sensíveis, pois ainda haveria a possibilidade de que a beleza pudesse ser atribuída a certos elementos não sensíveis. Uma outra resposta seria a de demonstrar que a moralidade não seria não sensível, senão que, na verdade, ela se apoiaria em elementos sensíveis que chamaríamos de morais. Assim, a beleza moral também não se distinguiria da forma de como a tradição usou a ideia de beleza. Como veremos, ambas as respostas são plausíveis e não há grandes problemas em adotar uma ou outra, ou mesmo ambas.

O filósofo James Shelley (2003, p. 373-375) argumentou que a proposição que diz que propriedades estéticas te- 
riam que necessariamente depender, ao menos em parte, de propriedades capazes de serem percebidas por algum dos cinco sentidos deve ser considerada falsa, pois, caso verdadeira, teríamos consequências indesejáveis para as artes, a saber, atividades artísticas que consideraríamos tradicionalmente como estéticas não seriam, e obras de arte contemporâneas não seriam realmente obras de arte. Além do que, certos objetos que consideraríamos como possuindo beleza, não a possuiriam. ${ }^{38}$

A primeira dessas consequências se torna aparente se considerarmos a literatura como um tipo de arte estética. Seria estranho afirmar que a literatura seria uma arte formal pura, ou que as suas propriedades estéticas se baseariam em elementos capazes de serem apreendidos pelos sentidos. Um dos pontos mais importantes da literatura é, exatamente, a relação do leitor com o conteúdo que ele lê. Além de esse conteúdo ser apresentado ao leitor através da relação semântica entre as palavras no texto, o que caracteriza a unidade da obra literária, há elementos estéticos além das palavras e das suas relações. $\mathrm{O}$ conteúdo que é expresso pelo texto também seria capaz de apresentar propriedades estéticas além da relação semântica entre as frases e, assim, estas não se apresentariam a nós através da sua forma. $\mathrm{O}$ impacto da literatura sobre nós é sentido através de sensibilidades que vão além dos nossos cinco sentidos.

Sem a possibilidade de apreensão das propriedades es-

\footnotetext{
${ }^{38}$ Shelley afirma que ainda teria um outro problema mais relevante nessa compreensão específica, no caso, ela se basearia em teorias que permitiriam a possibilidade de um apreciador de arte que nunca sentisse uma relação emocional com a arte. Mas tomamos como as consequências mais problemáticas para o ponto que estamos lidando as colocadas acima.
} 
téticas que se baseiam em elementos não sensoriais, Shelley afirma que a arte conceitual dificilmente possuiria as propriedades artísticas que atribuímos a elas. A fonte de Duchamp, p.ex., não teria as suas propriedades artísticas caso estas dependessem de propriedades não artísticas capazes de serem percebidas através dos nossos sentidos. ${ }^{39}$ Caso possuíssem, teríamos que admitir que outros urinóis semelhantes ao empregado por Duchamp apresentariam as mesmas propriedades artísticas, visto que não há como distingui-las através de suas propriedades físicas. Também, por vezes, atribuímos propriedades estéticas a conclusões científicas, como teoremas, proposições sobre a natureza e a física. Dizemos que algumas teorias seriam, p.ex., elegantes ou excitantes. Da mesma forma, poderia ser alegado que a teoria da evolução por seleção natural proposta por Charles Darwin seria horrível ou nojenta para algumas pessoas. Esses atributos são propriedades estéticas e elas afetam as emoções dos seus observadores. Diferentes objetos que observamos esteticamente não seriam mais considerados como estéticos, visto que a fonte da sua beleza se encontra em algo que não se apresenta aos nossos sentidos.

Ainda há a possibilidade de argumentarmos que um evento moral seria perceptível pelos sentidos. Um observador com tendências comportamentalista da ação e psicologia humana poderia facilmente afirmar que somente observamos as causas e os efeitos das ações, e ao perceber que

\footnotetext{
${ }^{39}$ Embora propriedades estéticas e artísticas possam ter diferenças conceituais dependendo da abordagem filosófica, essa distinção não seria relevante para o presente ponto, visto que, mesmo que elas apresentem diferenças conceituais, as suas propriedades seriam bem semelhantes, senão idênticas.
} 
uma ação geraria uma maior satisfação entre os envolvidos, inclusive nele próprio, que ele afirmaria que esta ação foi moral. É comum afirmarmos que uma ação foi uma ação moral por observarmos que uma pessoa, p.ex., se colocou em perigo para ajudar outrem, que a sua ação não foi, aparentemente, motivada por qualquer ganho imediato ou futuro, que a sua ação foi intencional e não coagida, etc. Não temos acesso aos seus estados e eventos mentais, somente ao seu comportamento, ou seja, ações, expressões, falas, etc. Desta forma, seria plausível afirmarmos que uma ação moral seria observável. Não são necessárias indagações metaéticas sobre propriedades morais ou sobre o estatuto semântico da linguagem moral para determinarmos se uma ação foi moral. Proceder desta forma não é como realmente agimos ou interpretamos ações morais no nosso cotidiano.

Por sua vez, podemos dizer que um evento seria moral se as ações que o compõem apresentassem propriedades morais. Da mesma que não observamos propriedades morais nas ações, mas atribuímos a elas através da nossa observação, também seria pela nossa observação que diríamos que um evento seria moral. Observamos os eventos e as ações humanas que fazem parte deles e somente através das suas causas e dos seus efeitos que atribuímos a eles diferentes qualidades, em especial, as qualidades morais.

Afirmar que propriedades morais não poderiam ser percebidas através dos nossos sentidos e, portanto, não poderiam ser uma base não estética de propriedades estéticas, ignora o fato de que a atribuição de propriedades morais a uma ação seria bem semelhante à atribuição de propriedades estéticas a performances artísticas, como a dança ou o teatro. Os envolvidos na dança ou no teatro não produzem 
um objeto, mas sim uma performance a ser esteticamente apreciada. Somente dizemos que a dança foi bonita após observarmos toda a performance. Apreciamos as ações dos diferentes performers, e ao vermos beleza, ao menos, na maioria dessas ações e como elas se integram formando uma unidade, que seríamos capazes de apreciar esteticamente a performance como um todo.

$O$ reconhecimento de que a atribuição de propriedades morais a um evento moral seria semelhante ao da apreciação estética de uma performance artística nos permitir compreender como propriedades morais seriam perceptíveis pelos sentidos assim como propriedades estéticas seriam possíveis em virtude de propriedades morais. Se atribuímos propriedades morais a um evento após a observação das suas ações e dos seus efeitos, e caso tenhamos experiencias estéticas a partir desta observação, consideraríamos que esta experiência estética foi causada pelas suas propriedades morais. A explicação seria, mais ou menos, pelas seguintes linhas: como um evento considerado moral seria um ao qual atribuiríamos propriedades morais e ele foi capaz de nos causar experiências estéticas, que ocorreriam somente se houvesse propriedades estéticas no evento, poderíamos dizer que as propriedades morais causaram as propriedades estéticas, pois a percepção de que o evento seria moral seria a causa dessa experiência estética.

Ambas as respostas mostram como seria possível solucionar o problema colocado por Carroll. Por um lado, caso ele esteja correto, teremos que abandonar parte de tipos de arte que consideraríamos como claramente estéticas, e, até mesmo, deixar de lado outras que, apesar de não serem estéticas, se baseiam em elementos não sensoriais. Essa seria 
uma consequência indesejável, contrária às nossas práticas artísticas. Por outro lado, a nossa prática moral demonstra bem como atribuímos propriedades morais através da análise das causas e efeitos das ações que observamos. Não dizemos que essas ações são morais por observarmos propriedades morais nelas, mas sim que elas teriam propriedades morais por envolverem causas e efeitos de certos comportamentos que já consideramos de antemão como morais. A nossa prática moral não se afasta dos nossos cinco sentidos.

Porém, embora o problema de Carroll tenha sido satisfatoriamente resolvido, a nosso ver, ainda há a questão levantada por Stecker. Caso não tenhamos uma proposta adequada para fundamentar a atribuição de propriedades estéticas a eventos morais, seria plausível afirmar, como ele fez, que isso seria uma mera forma de falar. Faz-se necessário, portanto, buscar uma proposta adequada para fundamentar a hipótese da beleza moral, e, para isso, como já dito acima, nos apoiaremos na abordagem de Hume.

\section{BELEZA MORAL EM DAVID HUME}

Ao analisarmos a abordagem estética de Hume, fica claro que ele é um proponente da abordagem orientada ao afeto. Conforme o filósofo escocês, a experiência estética é composta por um complexo de impressões e ideias, em especial, impressões secundárias, que seriam responsáveis pela força emotiva que a arte poderia gerar em nós. Igualmente, o seu entendimento da moralidade perpassa por esse complexo de impressões e ideias. A impressão secundária é, novamente, central para a compreensão da força motivacional da a- 
ção moral. Desta forma, faz-se necessário analisar como ele entende as relações internas da mente humana para uma correta compreensão de sua teoria moral e estética, e como essas estariam interrelacionadas de forma a possibilitar a beleza moral.40

Todo o sistema filosófico de Hume $(2007,1.1 .1 .1)$ se fundamenta no seguinte postulado: "As percepções da mente humana se reduzem a dois géneros distintos, que chamarei de IMPRESSÕES e IDÉIAS." ${ }^{41}$ Não importa se dissertamos sobre a sua compreensão acerca dos fundamentos do conhecimento humano ou sobre os princípios da moralidade e do gosto [taste], o correto entendimento do que as impressões e ideias em Hume seriam é um pressuposto para a correta compreensão das diferentes partes de sua filosofia. . ${ }^{22}$ Com isso, faz-se necessário começar a nossa investigação em Hume a partir desse ponto.

Hume chama de "impressões" as percepções às quais teríamos um acesso imediato assim que elas se apresentassem para nós. Impressões seriam fortes e vívidas, aparecem em nós com pujança. Por sua vez, ele define as ideias como imagens fracas que se apresentariam para o sujeito no pensamento e na razão. Hume considera, em um primeiro

\footnotetext{
${ }^{40}$ A teoria moral de Hume possui inúmeras questões complexas, e comentadores com abordagens distintas possuem, em diversos casos, entendimentos contraditórios acerca do mesmo ponto. $\mathrm{O}$ presente texto não lidará com essas questões, somente buscando apresentar uma possivel interpretação de sua teoria moral e estética que possibilitaria a postulação da existência da beleza moral.

${ }^{41}$ As citações em português são da edição brasileira do Tratado sobre a Natureza Humana [A Treatise of Human Nature] da editora UNESP. Por ser uma tradução oficial, não há as citações na língua original da obra nas notas. As referências diretas e indiretas seguem o formato normalmente empregado pela literatura secundária: o livro do Treatise, a sua parte, a seção e o parágrafo, e correspondem a ambas as edições.

${ }^{42}$ A teoria estética de Hume disserta sobre o que ele chamou de "gosto". Por gosto podemos entender o que atualmente compreendemos por estética filosófica.
} 
momento, que a diferença entre ambas seria somente a força com as quais elas surgem para nós. Há ainda outras divisões que se tornam importantes para a compreensão da moralidade e da estética. Uma dessas divisões seria a entre impressões originais e impressões secundárias (HUME, 2007, 2.1.1.1-2).

A impressão original seria aquela impressão que surge imediatamente pelos sentidos, à qual imputamos fontes externas, pois não sabemos, realmente, as suas causas. Mas há outros caminhos através dos quais esses tipos de impressões podem aparecer nos sujeitos. Talvez, o mais importante destas sejam as sensações da dor e do prazer. Ainda que relacionemos essas impressões com pretensos objetos externos, no caso, o objeto $O$ causaria a dor $d$, nós não a percebemos, de fato, nesses fatores externos. Podemos imputar diretamente a um objeto externo uma determinada extensão, peso, cor etc., mas não há como dizermos, ao menos de forma direta, que um objeto causaria prazer ou dor. Hume afirma que as sensações: "surgem na alma sem nenhuma percepção anterior, pela constituição do corpo, pelos espíritos animais, ou pela aplicação dos objetos sobre os órgãos externos." (2007, 2.1.1.1). O estabelecimento de uma conexão entre o prazer e a dor com um objeto considerado externo ao sujeito se torna possível com as impressões secundárias, ou, mais propriamente, reflexões.

As reflexões são impressões que surgem de impressões originais ou de ideias de impressões passadas. Neste ponto, a impressão secundária seria uma nova sensação que surge em nós a partir de uma impressão original ou de uma ideia. Essas novas sensações são diversas e admitem outras divi- 
sões. As reflexões podem ser calmas, que, por terem esta característica, seriam, em diferentes casos, confundidas com as ideias resultante das operações da razão, possivelmente responsável por conectar os prazeres e as dores com os objetos externos que se mostram no momento pelas sensações (HUME, 2007, 2.3.3.8). Mas, segundo Hume, nem toda reflexão seria calma, ao contrário, talvez a grande maioria delas seriam, como ele chamou, violentas. ${ }^{43}$ Dada a força dessas impressões secundárias, ele afirma que seria apropriado chamá-las de paixões, pois elas movem os seres humanos e moldam afetivamente as suas percepções acerca do mundo.

As paixões se caracterizam por sua conexão com os prazeres e dores que surgiram nos indivíduos. Dependendo de sua relação com essa sensação, elas podem ser diretas ou indiretas (HUME, 2007, 2.1.1.3). As paixões diretas possuem sua fundamentação e fio motor diretamente na dor e no prazer, que são base do sentido mais simples dos termos "bom" e "mau". Por paixões indiretas, Hume entende aquelas que, além do prazer e da dor como fundamento, possuem outras qualidades importantes para o seu aparecimento. Neste caso, a dor e o prazer não são suficientes para levarem o indivíduo a ter uma paixão desse tipo, outros aspectos se tornam necessários e, possivelmente, caracterizam o tipo de paixão que o acometeu. Hume afirma que tanto as ações morais quanto as experiências estéticas são configuradas por essa outra qualidade.

$\mathrm{Na}$ seção sobre vícios e virtudes, no livro das paixões do Treatise, Hume se pergunta: "se essas distinções morais se

\footnotetext{
${ }^{43}$ Hume admite que essas divisões não são precisas, e que deveríamos considerá-las como generalizações e não princípios universais.
} 
fundam em princípios naturais e originais ou se nascem do interesse e da educação.” (2007, 2.1.7.2). Essa pergunta é a clássica questão acerca dos fundamentos da ação moral dos seres humanos, se eles se encontram nos seres humanos e seriam, desta forma, inatos, ou se faz-se necessário um ensino moral, capaz de socializar os indivíduos e internalizar princípios morais nestes. Embora ele afirme que responderia a essa questão somente no terceiro livro, o que disserta diretamente sobre a moralidade, ele assume já no segundo livro a posição pela qual ele argumentará no livro seguinte, a saber, de que a moralidade não seria inata, mas consequência de uma educação moral e do autointeresse.

A moralidade se funda nas paixões, mais especificamente, no prazer e na dor com a conjunção de uma outra qualidade (HUME, 2007, 3.1.2.1-3). Aprovar alguém ou a sua ação significa ter um prazer frente a ele ou a sua ação. Ao contrário, desaprovar significa estar propenso a uma sensação de desprazer com o seu caráter ou com as suas ações. No entanto, meramente ter prazer ou dor com a ação ou o caráter de outrem não seria o suficiente para fundar a moralidade, pois alguém poderia me causar prazer, e ainda que eu pudesse aprovar esse prazer por ser algo bom para mim, isso não significaria que eu teria aprovado moralmente a sua ação ou o seu caráter. Nossas experiências cotidianas mostram que a aprovação moral envolve mais que o próprio bem-estar ou interesse. Ademais, sem essa outra qualidade, não seria possível distinguirmos entre um prazer comum e o prazer gerado pela ação ou caráter moral, e teríamos que atribuir propriedades morais a objetos externos. Hume afirma que sentimos este prazer por causa da ação moral, e 
não que uma ação seria moral por sentirmos prazer com ela. Isso se torna possível pela qualidade da simpatia.

Tal como concebida pelo filósofo escocês, a simpatia não significa ter uma "boa impressão" ou exibir uma afinidade com outrem, mas sim a disposição para compreender os sentimentos ou desejos de outrem através da imaginação. A simpatia seria capaz de realizar essa atividade através dos poderes da imaginação, o que introduziria um aspecto racional na moralidade. O seguinte trecho (2007, 2.1.11.7-8) deixa bem claro como a simpatia e a imaginação estariam intimamente conectadas em Hume:

[...] [nossos afetos] surgem mais naturalmente da imaginação e das idéias vívidas que deles formemos. Tal é a natureza e a causa da simpatia [...] quando simpatizamos com as paixões e sentimentos alheios, de início esses movimentos aparecem em nossa mente como meras idéias, e nós os concebemos como pertencendo a uma outra pessoa [...] as idéias dos afetos alheios se convertem nas próprias impressões que elas representam, e que as paixões nascem em conformidade com as imagens que delas formamos. [...] Pois, para além da relação de causa e efeito, que nos convence da realidade da paixão com que simpatizamos, precisamos das relações de semelhança e contiguidade para sentir a simpatia em sua plenitude. [...] a simpatia corresponde exatamente às operações de nosso entendimento [...].

De acordo com Hume, a simpatia seria um processo de inferência realizada por uma análise do comportamento de outrem, pela qual determinaríamos as suas sensações, emoções e, até mesmo, crenças. Ele afirma que: "Nenhuma paixão alheia se revela imediatamente à nossa mente. Somos sensíveis apenas a suas causas ou efeitos. É desses que inferimos a paixão; consequentemente, são eles que geram nossa simpatia." (HUME, 2007, 3.3.1.7). Enquanto seres humanos, não possuímos um acesso direto aos pensamen- 
tos de outrem, somente ao seu comportamento. Através da observação de como alguém se comporta, podemos imaginar como ele se sente. A nossa imaginação constrói uma ideia sobre as sensações do outro, e essa ideia pode se transformar em impressão, e, por sentirmos prazer ou dor a partir desta impressão que formamos da ideia, ela se torna uma paixão, e somos capazes de entender como o outro se sente por experenciarmos uma paixão semelhante a sua e, assim, nos sentiríamos motivados a agir em prol dessa pessoa:

Quando um afeto se transmite por simpatia, nós a princípio o conhecemos apenas por seus efeitos e pelos signos externos, presentes na expressão do rosto ou nas palavras, e que dele nos fornecem uma idéia. Essa idéia imediatamente se converte em uma impressão, adquirindo um tal grau de força e vividez que acaba por se transformar na própria paixão, produzindo uma emoção equivalente a qualquer afeto original. (HUME, 2007, 2.1.11.3)

Hume naturaliza o funcionamento da simpatia, que se torna totalmente explicável pelos princípios mais básicos da natureza humana, e, com isso, ele se afasta dos seus antecessores que postulavam a existência de um senso moral [moral sense], caso este seja entendido como uma faculdade especifica e genuina (TAYLOR, 2002, p. 49-50). Não obstante, se entendermos essa noção como uma mera capacidade de discernir as virtudes dos vícios, então, poderíamos admitir que Hume teria defendido um tipo de senso moral, pois a simpatia, ao lado da imaginação, estabelece as paixões adequadas que nos levariam a compreender quais ações seriam as corretas, tanto as nossas quanto as de outros. ${ }^{44}$

\footnotetext{
${ }^{44}$ Ao comentar a posição moral de Hume, a filósofa Rachel Cohon (2008, p. 98-113) diz que o Cont.
} 
A simpatia também se apresenta como um recurso estético dos observadores para aproximá-los do artista e de sua obra (TOWNSEND, 2001, p. 100-105). O entendimento da obra se faz a partir de um conhecimento já acumulado pelas pessoas, e, ao acessarmos os nossos conhecimentos para analisar a obra de arte, pensamos o que o artista queria expressar, a que a forma daquilo que observo me remete, etc. Ademais, a simpatia faz uso da imaginação para buscar responder as questões que o observador se coloca, sendo capaz de estabelecer uma conexão emocional entre a obra de arte e o observador. Artes que se baseiam na interpretação, p.ex., seriam as que mais se baseariam nessa capacidade, pois sem uma conexão emocional e o conhecimento comum compartilhado entre o observador e o artista, não seria possível que o observador realmente interpretasse a obra de arte.

Mas a simpatia não seria o único fundamento da moralidade e da beleza em Hume. Ele afirma que seria impossível a construção de costumes morais a partir dessa capacidade, afinal, ela lida diretamente com os outros. Através da simpatia podemos compreender o sofrimento de um outro e nos sentir motivados a ajudá-lo, mas não seria possível partir desta ação singular para a construção de costumes morais para a sociedade. A simpatia também se mostraria limitada para a avaliação desses costumes morais, pois não há como saber, somente pela simpatia, os efeitos dos costumes morais sobre os indivíduos. Assim, se quiser-

mais preciso seria denominar a sua posição como "moral sensing view", para distingui-la da noção de senso moral, em especial, a de Hutcheson, que colocaria o senso moral como uma faculdade própria e específica. 
mos explicar os fundamentos dos costumes morais, assim como a nossa capacidade crítica a estes, torna-se necessário um outro princípio que não seja a simpatia. Ao fim do $A$ Treatise of Human Nature e ao longo do An Enquiry concerning the Principles of Morals, Hume considera outros dois princípios como sendo importantes para os fundamentos dos costumes morais e para a determinação da ação correta. Ele entende a utilidade [utility] e a agradabilidade [agreeableness] como esses outros princípios.

Ao contrário do conceito de simpatia, que se tornou para o filósofo escocês um termo técnico, afastado do seu uso cotidiano, a utilidade empregada por ele seria o mesmo que empregamos cotidianamente, no caso, uma virtude seria útil caso ela tivesse a propensão de produzir efeitos positivos para a sociedade (HUME, 1902, p. 215-218). Em diferentes momentos em ambos os textos, ele tendeu a falar de vantagem ao invés de utilidade. Mas, ambos os termos se referem ao mesmo aspecto de objetos ou das ações, que elas seriam vantajosas ou úteis caso elas tivessem a disposição de gerar fins positivos para aquele que as emprega. No caso de virtudes, a utilidade tende a criar a sensação de prazer característica das ações virtuosas para a sociedade. Ao sentirmos o prazer característico das ações virtuosas por causa das ações úteis, tendemos a aprovar moralmente aquelas ações que nos geram esse prazer, pois as identificamos como ações virtuosas. ${ }^{45}$ No Enquiry (1902, p. 219), Hume afirma

\footnotetext{
${ }^{45}$ Deve-se, contudo, não confundir o emprego do termo "utilidade" por Hume como um indício de que ele seria utilitarista. Embora possamos, de fato, estabelecer conexões entre a concepção moral de Hume com as dos autores utilitaristas, o termo "utilidade" possui sentidos diferentes. Como já foi dito, Hume o emprega como o entendemos cotidianamente, como algo que seria útil para nós e que, por isso, nos produziria felicidade. Por sua vez, os filósofos Jeremy Bentham e Cont.
} 
que:

A utilidade é apenas uma tendência para um determinado fim [...] Caso a utilidade, portanto, seja fonte de sentimento moral, e caso essa utilidade seja nem sempre considerada com referência ao eu [self]; segue-se que tudo o que contribui para a felicidade da sociedade recomenda a si mesmo diretamente à nossa aprovação e boa vontade. Aqui está um princípio que explica, em grande parte, a origem da moralidade. ${ }^{46}$

Assim, tanto a moralidade quanto a beleza se fundamentam, ao menos em parte, na utilidade (HUME, 2007, 2.1.8.2). Há, porém, uma diferença de como a utilidade se apresenta nos juízos morais e nos juízos estéticos ou de gosto. Enquanto nos juízos morais a utilidade é pensada como utilidade pública, vemos que nos juízos estéticos a utilidade se apresenta somente como um critério de julgamento, e não considera se a obra de arte possuiria uma utilidade pública. Hume aponta para o fato de que a atribuição de beleza a certos objetos comuns, embora possa se basear em sua utilidade, essa utilidade seria somente dos donos de tais objetos, enquanto observadores teriam que se apoiar em outras qualidades do objeto ou usar a simpatia para essa atribuição de beleza.

Normalmente aparecendo ao lado da utilidade, a agradabilidade seria uma outra qualidade das ações que nos influenciariam a chamá-las de virtuosas. De acordo com

John Stuart Mill utilizam esse termo como um termo técnico, com diferenças de sentido em relação a seu uso cotidiano. (BAIER, 1991, p. 250)

${ }^{46}$ Usefulness is only a tendency to a certain end [...] If usefulness, therefore, be a source of moral sentiment, and if this usefulness be not always considered with a reference to self; it follows, that everything, which contributes to the happiness of society, recommends itself directly to our approbation and good-will. Here is a principle, which accounts, in great part, for the origin of morality. 
Hume, essa sensação de agradabilidade é simplesmente sentida. Enquanto a determinação da ação virtuosa pela simpatia e sua utilidade exige, normalmente, o emprego das nossas faculdades racionais, há certas ações que chamamos de virtuosas não por apresentarem utilidade ou por, através da simpatia, agirmos de forma adequada em favor de outrem, mas sim por elas terem a qualidade de serem imediatamente agradáveis. A agradabilidade se conecta com o prazer típico da ação virtuosa, o que confere a esta ação a qualidade de agradabilidade intrínseca, ou seja, uma agradabilidade em realizar o ato. Essas ações são agradáveis por possuírem uma tendência natural de produzirem em nós a sensação de prazer moral, e nos motivaria a agir virtuosamente pelo simples fato da ação ser virtuosa. (HUME, 2007, 3.3.1.28-29).

Um ponto extremamente interessante que Hume levanta é que esta sensação de agradabilidade imediata não se conecta com qualquer tipo de interesse público, ou seja, essas virtudes podem ser agradáveis sem que elas sejam úteis. Simplesmente dizemos que elas são agradáveis e virtuosas por sentirmos que elas são desta forma. Neste ponto, ele afirma que saberíamos simplesmente pelo gosto [taste]:

sou da opinião de que a reflexão sobre as tendências das ações tem de longe a maior influência e determina as grandes linhas de nosso dever. Entretanto, há exemplos de casos menos importantes em que é o gosto ou sentimento imediato que produz nossa aprovação. [...] Algumas dessas qualidades produzem satisfação nos demais por meio de princípios particulares originais à natureza humana, que não podem ser explicados [...]. (HUME, 2007, 3.3.1.27)

$\mathrm{Na}$ seção sobre virtude e vícios no Treatise, ele afirma que o gosto seria responsável para distinguirmos as quali- 
dades que atribuímos às ações virtuosas e aos vícios dos demais prazeres, no caso, gosto é responsável para identificarmos os prazeres e dores específicos da moralidade: "[...] o que é esse gosto [...] [e]videntemente, não é nada mais que uma sensação de prazer suscitada pelo verdadeiro espírito, e de desprazer pelo falso, sem que sejamos capazes de dar as razões desse prazer ou desprazer." (2007, 2.1.7.7)

Essa relação da virtude com o que ele chamou de gosto nos aproxima, assim, ao entendimento da experiência estética defendida pela abordagem orientada ao afeto e, principalmente, à conexão entre a moralidade e a estética. Ao analisar os nossos motivos para afirmarmos que um objeto seria bonito, Hume afirma que, semelhante à moralidade, a beleza é atribuída a um objeto por ele nos causar um prazer ou dor específica (2007 2.1.8.1-3). Mais uma vez ele emprega o gosto como a capacidade específica através da qual determinaríamos as qualidades de um objeto ou evento, nesse caso, as qualidades estéticas.

Com relação à agradabilidade imediata, o fato de essa qualidade se apresentar pelo gosto faz com que ela seja também mais um aspecto que aproxima a moralidade e estética. Além disso, é interessante como essa qualidade faz com que nos aproximemos de um dos critérios acerca da experiência estética, a saber, da imediação. Ao observarmos um objeto ou evento ao qual atribuímos propriedades estéticas, esse objeto ou evento pode ter essa qualidade da agradabilidade imediata, dependendo de como ele foi construído.

Hume parece também considerar os demais aspectos ao afirmar que as obras de arte devem ser consideradas pelo 
seu todo e não pelas suas partes, o que o aproximaria do aspecto da unidade da experiência estética. $\mathrm{O}$ desinteresse seria, ao contrário, menos um aspecto da experiência estética do que um critério para o bom juízo estético. ${ }^{47}$ Ele não considera algum conceito específico semelhante ao do desinteresse, porém, ele diz que o bom juízo estético somente seria bem executado se o crítico se livrasse de todos os preconceitos [prejudice] e se focasse somente na obra de arte, visto que o preconceito poderia destruir o bom juízo estético (HUME, 1987, p. 239-240).

Seguindo o tratamento dado por Hume à moralidade e à estética, torna-se possível responder à questão de Stecker. Sua teoria estética se aproxima, claramente, à abordagem orientada ao afeto, ao exibir uma grande similaridade aos pontos mais relevantes desta, sobretudo ao fato de que a experiência estética se caracterizaria, centralmente, como um prazer específico. Tanto a utilidade quanto a agradabilidade imediata são os fundamentos desse prazer específico, pois ele defende que ambas as qualidades são conducentes a esse prazer. Por sua vez, a simpatia nos aproxima da obra de arte e do artista, pois interpretamos as suas intenções e os possíveis significados da sua obra, sendo, inclusive, capaz de criar uma relação emocional entre a obra de arte e o observador.

A ação moral possui as mesmas bases que a experiência estética e se caracteriza por um comportamento útil e que nos causar um prazer específico fundamentado na simpatia. Há duas possibilidades de lidarmos com a hipótese da bele-

${ }^{47}$ Hume chamou a prática do juízo estético de crítica [criticism]. 
za moral neste ponto. Uma delas seria a de presumir que os mesmos fatores que nos motivam moralmente também causam a experiência estética. A outra diria que propriedades morais causariam as propriedades estéticas. Esta segunda possibilidade seria problemática por comprometer o indivíduo com uma ontologia de fatos morais, caso queiramos que as propriedades morais sejam causalmente eficazes, como já foi dito. Todavia, não há propriedades morais ou estéticas reais para Hume, somente os prazeres específicos que sentiríamos causados em nós por características não morais e não estéticas. A percepção de que determinados objetos ou eventos nos causam esses prazeres específicos faz com que lhes atribuamos propriedades que, na verdade, não possuiriam. Essas propriedades morais e estéticas são projetadas aos eventos aos quais atribuímos a causa de tais prazeres.

A atribuição de propriedades estéticas a eventos morais se dá exatamente por essa mesma base não moral e não estética ser a mesma. Ao observarmos uma ação qualquer, a interpretamos através da simpatia, caso queiramos entender como outros agem. Isso faz com que certas ações possam nos afetar de diferentes formas. Ações morais ou virtuosas se colocam para o seu observador como uma ação que pode apresentar agradabilidade ou utilidade, e, através da simpatia, ele interpreta a ação, o que produz certas paixões nele, entre elas, um prazer específico, característico do que consideramos moral.

Mas, ao mesmo tempo, ao percebermos que a ação seria moral, e que apresentaria agradabilidade ou utilidade, há uma nova consideração desta utilidade ou agradabilidade pela simpatia. Pela ação moral nos causar um prazer especí- 
fico, podemos afirmar que ela seria imediatamente agradável. Além disso, dado que as ações morais são ações que contribuem para a felicidade dos envolvidos, elas também se mostram como úteis. Desta forma, podemos dizer que o evento moral nos causaria um tipo de prazer específico além do prazer moral, a saber, o prazer estético. Teríamos uma experiência estética a partir das características que a ação moral exibiria. Igualmente, o desprazer da ação imoral criaria uma experiência estética em nós, somente que denominaríamos essa ação como feia, horrorosa, nojenta, etc. A beleza moral não seria somente uma forma de falar.

O mecanismo através do qual Hume concebe a ação moral e a experiencia estética faz com que seja possível a beleza moral. Inclusive, em diversos momentos do Treatise e do Enquiry, Hume se refere ao prazer específico que sentiríamos com a ação moral de beleza moral. Ele próprio reconhece que essa similaridade seria mais do que uma forma de falar. Há uma relação forte entre a moralidade e a estética, relação esta que permite que ações morais se apresentem para nós como belas ${ }^{48}$. O seguinte trecho $(1902$, p. 173) deixa claro como, para o autor, a moralidade poderia possuir uma beleza, ou ela mesma ser um tipo de beleza:

Algumas espécies de belezas, principalmente as naturais, em sua primeira aparição, merecem nosso afeto e aprovação [...] Mas em muitas ordens de beleza, principalmente as das belas artes, é necessário empregar muito raciocínio, a fim de sentir o sentimento adequado [...] Há motivos justos para concluir que a beleza moral participa muito desta última espécie e exige o auxílio de nossas faculdades in-

\footnotetext{
${ }^{48}$ Diferentes comentadores e críticos reconhecem essa forte conexão entre a sua filosofia moral e estética, entre eles D. D. Raphael (1947, p. 71-90), Peter Kivy (1983) Dabney Townsend (2001, p. 86-157), e Timothy M. Costelloe (2007).
} 
telectuais, a fim de dar-lhe uma influência adequada sobre a mente humana. ${ }^{49}$

\section{CONCLUSÃO}

$\mathrm{O}$ presente artigo buscou defender que a hipótese da beleza moral seria factível, e não um erro categorial ou um mero jogo de linguagem. Essa hipótese postula que alguns eventos morais seriam capazes de nos proporcionarem experiências estéticas. Além de propriedades morais, estes eventos também apresentariam propriedades estéticas. Nossas experiencias e linguagem moral cotidiana fazem com que a hipótese da beleza moral seja plausível. É comum a atribuição de termos estéticos a eventos morais assim como termos experiencias estéticas causadas por eventos morais. No entanto, sem uma justificativa que seja capaz de explicar como essa atribuição poderia se dar, a acusação de erro categorial não se dissipa. Assim, se torna necessário explicar como propriedades morais e estéticas poderiam se relacionar e como experiências estéticas a partir de eventos morais seriam possíveis.

Dentre as possíveis relações entre propriedades morais e propriedades estéticas, a que se mostra mais interessante, e menos contenciosa, seria a relação causal. A relação causal poderia explicar de forma eficaz como propriedades estéticas surgiriam das morais, a saber, as propriedades morais

\footnotetext{
${ }^{49}$ Some species of beauty, especially the natural kinds, on their first appearance, command our affection and approbation [...] But in many orders of beauty, particularly those of the finer arts, it is requisite to employ much reasoning, in order to feel the proper sentiment [...] There are just grounds to conclude, that moral beauty partakes much of this latter species, and demands the assistance of our intellectual faculties, in order to give it a suitable influence on the human mind.
} 
causam as estéticas. Da postulação de que uma relação causal entre ambas as propriedades seria capaz de explicar a hipótese da beleza moral, faz com que a seguinte questão surja: se há uma relação causal entre essas propriedades, como essa se daria? A defesa de que há propriedades subjacentes às morais e estéticas que as causariam e que a relação entre elas seria estabelecida por estas propriedades subjacentes seria a mais razoável por deixar de lado uma série de problemas, como o sobre o estatuto ontológico das propriedades morais.

O entendimento de Hume sobre a atribuição de propriedades estéticas e morais a eventos permitiria que compreendamos como, em alguns casos, eventos morais poderiam nos causar experiências estéticas. Por ser capaz de explicar como essa relação causal poderia se dar sem necessitar postular uma eficácia causal de propriedades morais, a sua proposta moral e estética seria a que melhor se encaixa com a abordagem causal adotada. Contudo, sem uma concepção adequada da experiência estética capaz de acomodar a proposta moral e estética humeana, ainda existiria um déficit explicativo na hipótese da beleza moral, visto que deixaria de lado a explicação do ponto mais intuitivo desta hipótese, o de que temos genuínas experiencias estéticas a partir de eventos morais.

Duas concepções da experiência estética se mostram como plausíveis. Uma delas evoca o fato de que reagimos a objetos e eventos e que atribuímos propriedades estéticas a eles a partir de uma relação perceptual que estabelecemos com eles. Somos capazes de identificar estas propriedades nestes objetos e eventos através da nossa percepção deles. Por sua vez, há uma outra proposta que se baseia não em 
uma relação cognitiva com os objetos e eventos estéticos, mas sim uma afetiva. Atribuiríamos propriedades estéticas a estes objetos e eventos não por sermos capazes de identificar essas propriedades neles, mas por sentirmos um tipo específico de prazer, um que chamaríamos de estético. Esta abordagem, denominada por Carroll como orientada ao afeto, se mostra como a mais interessante por dois motivos. $\mathrm{O}$ primeiro por possuir uma afinidade com a proposta moral e estética de Hume. $O$ segundo por nos permitir responder a crítica de Carroll de que haveria um erro categorial em atribuir propriedades estéticas a eventos morais.

A compreensão de Hume da moralidade e da estética nos permite observar como a sua abordagem, ou uma baseada nesta, seria capaz de prover uma justificativa para que aceitássemos a hipótese da beleza moral como verossímil. Essa plausibilidade conferida à hipótese da beleza moral faz com a atribuição de beleza a eventos morais seja mais do que "uma mera forma de falar", pois a beleza moral seria mais que um jogo de linguagem, mas uma prática que faz sentido e que tem uma boa explicação para ocorrer.

Além disso, a possibilidade de dar uma base à parte da nossa linguagem moral que faz uso de termos estéticos a partir da teoria moral e estética proposta por Hume confere uma certa plausibilidade tanto às teorias morais antirrealistas quanto às teorias estéticas que explicam a experiência estética através dos moldes da abordagem orientada ao afeto. Caso o realista moral e/ou estético queira continuar negando as abordagens antirrealistas na moralidade e na estética, ele tem que ser capaz de explicar como a beleza moral seria possível. Claro, ele poderia, simplesmente, resolver 
perdurar na afirmação de que a beleza moral seria uma confusão categorial, como Carroll e Stecker fizeram. No entanto, isso nos afastaria de nossa prática moral cotidiana, e, como McGinn argumentou, tornaria a nossa linguagem moral bem mais pobre.

Abstract: The present article aims to defend the possibility of the existence of moral beauty based on contemporary analytical approaches to aesthetics and David Hume's moral and aesthetic theory. Different relationships between aesthetics and morality will be analyzed in the first part. The hypothesis of moral beauty will be placed as one of these possible relationships. Within the possibilities of grounding moral beauty, it will be argued that the best one would be through a Humean understanding of aesthetics and morality. The second part of the article analyzes the concept of aesthetic experience and its importance for the Humean foundation of moral beauty. Finally, the moral and aesthetic theory proposed by Hume will be developed in order to demonstrate how the hypothesis of moral beauty could be justified.

Keywords: moral beauty; aesthetic experience; moral aesthetics in David Hume; contemporary analytic aesthetics.

\section{REFERÊNCIAS}

ANNAS, J. An Introduction to Plato's Republic. Oxford: Clarendon Press, 1981.

ARISTOTLE. Aristotle's Metaphysics: books M and N. Oxford: Clarendon Press, 1976.

ARISTOTLE. Poetics: with the Tractatus Coislinianus, reconstruction of Poetics II, and the fragments of the On Poets. Indianapolis: Hackett Publishing Company, 1987.

BAIER, A. C. A Progress of Sentiments: reflections on Hume's Treatise. Cambridge: Harvard University Press, 1991. 
BARNES, E. Explaining brute facts. PSA: Proceedings of the Biennial Meeting of the Philosophy of Science Association, v. 1994, n. 1, p. 61-68, 1994.

BARNEY, R. Notes on Plato on the kalon and the good. Classical Philology, v. 105, n. 4, p. 363-377, 2010.

BEARDSLEY, M. C. The aesthetic point of view. In: BEARDSLEY, M. C. The Aesthetic Point of View: selected essays. Ithaca: Cornell University Press, 1982a. p. 15-34.

Aesthetic experience regained. In: BEARDSLEY, M. C. The Aesthetic Point of View: selected essays. Ithaca: Cornell University Press, 1982b. p. 77-92.

. Aesthetic experience. In: BEARDSLEY, M. C. The Aesthetic Point of View: selected essays. Ithaca: Cornell University Press, 1982c. p. 285-297.

BEARDSMORE, R. W. Art and Morality. London: Macmillan Education, 1971.

BLACKBURN, S. Ruling Passions: a theory of practical reasoning. Oxford: Clarendon Press, 1998.

CARROLL, N. Philosophy of Art: a contemporary introduction. London: Routledge, 1999.

. Colin McGinn, Ethics, Evil, and Fiction. Nô̂s, v. 34, n. 4, p. 648-656, 2000.

. Moderate moralism. In: CARROLL, N. Beyond Aesthetics: philosophical essays. New York: Cambridge University Press, 2001. p. 293-306. 
Four concepts of aesthetic experience. In: CARROLL, N. Beyond Aesthetics: philosophical essays. Cambridge: Cambridge University Press, 2003. p. 41-62.

- Aesthetic experience: a question of content. In: CARROLL, N. Art in Three Dimensions. New York: Oxford University Press, 2010a. p. 77-108.

Aesthetic experience, art, and artists. In: CARROLL, N. Art in Three Dimensions. New York: Oxford University Press, 2010b. p. 119-139.

COHON, R. Hume's Morality: feeling and fabrication. New York: Oxford University Press, 2008.

COSTElloE, T. M. Aesthetics and Morais in the Philosophy of David Hume. New York: Routledge, 2007.

CRITTENDEN, P. Ethics and aesthetics in Aristotle's Poetics. The Sydney Society of Literature and Aesthetics, v. 1, p. 15-27, 1991.

DICKIE, G. Taste and attitude: the origin of the aesthetic. Theoria, v. 39, n. 1-3, p. 153-170, 1973.

DOVER, K. J. Greek Popular Morality: in the time of Plato and Aristotle. Oxford: Basil Blackwell, 1974.

FREELAND, C. A. Plot imitates action: aesthetic evaluation and moral realism in Aristotle's Poetics. In: RORTY, A. O. Essays on Aristotle's Poetics. Princeton: Princeton University Press, 1992. p. 111-132.

GAUT, B. Art, Emotion and Ethics. New York: Oxford University Press, 2007. 
GOLDMAN, A. H. Aesthetic qualities and aesthetic value. The Journal of Philosophy, v. 87, n. 1, p. 23-37, 1990.

. Realism about aesthetic properties. The Journal of Aesthetics and Art Criticism, v. 51, n. 1, p. 31-37, 1993.

GOLDMAN, A. H. Aesthetic Value. New York: Routledge, 1995.

GUYER, P. Is ethical criticism a problem? A historical perspective. In: HAGBERG, G. L. Art and Ethical Criticism. Oxford: Blackwell Publishing, 2008. p. 3-32.

HALLIWELL, S. The Aesthetics of Mimesis: ancient texts and modern problems. Princeton University Press: Princeton University Press, 2002.

HAVELOCK, E. A. Preface to Plato. Cambridge: Belknap Press of Harvard University Press, 1963.

HUME, D. Enquiries Concerning the Human Understanding and The Principles of Morals. $2^{\mathrm{a}}$. ed. Oxford: Clarendon Press, 1902.

. Of the standard of taste. In: HUME, D. Essays: moral, political and literary. edição revisada. ed. Indianapolis: Libert Fund, 1987. p. 226-249.

- Tratado da Natureza Humana: uma tentativa de introduzir o método experimental de raciocínio nos assuntos morais. $2^{\text {a }}$. ed. São Paulo: UNESP, 2000.

A Treatise of Human Nature: a critical edition. New York: Oxford University Press, v. 1, 2007.

IRVIN, S. The pervasiveness of the aesthetic in ordinary 
experience. The British Journal of Aesthetics, v. 48, n. 1, p. 29-44, 2008.

IRWIN, T. H. The sense and reference of kalon in Aristotle. Classical Philology, v. 105, n. 4, p. 381-396, 2010.

JAEGER, W. Paideia: a formação do homem grego. $6^{\mathrm{a}}$. ed. São Paulo: Editora WMF Martins Fontes, 2013.

JANAWAY, C. Plato. In: GAUT, B.; LOPES, D. M. The Routledge Companion to Aesthetics. $3^{\mathrm{a}}$. ed. Oxon: Routledge, 2013. p. 3-12.

JANKO, R. From catharsis to the aristotelian mean. In: RORTY, A. O. Essays on Aristotle's Poetics. Princeton: Princeton University Press, 1992. p. 341-358.

KIERAN, M. Art, imagination, and the cultivation of morals. The Journal of Aesthetics and Art Criticism, v. 54, n. 4, p. 337-351, 1996.

KIM, J. Concepts of supervenience. In: KIM, J. Supervenience and Mind. Cambridge: Cambridge University Press, 1993a. p. 53-78.

. Supervenience as a philosophical concept. In:

Supervenience and Mind. Cambridge: Cambridge University Press, 1993b. p. 131-160.

KIVY, P. Hume's neighbour's wife: an essay on the evolution of Hume's aesthetics. The British Journal of Aesthetics, v. 23, n. 3, p. 195-208, 1983.

KORSMEYER, C. On distinguishing "aesthetic" from "artistic". The Journal of Aesthetic Education, v. 11, n. 4, 
p. 45-57, 1977.

KOSMAN, A. Beauty and the good: situating the kalon. Classical Philology, v. 105, n. 4, p. 341-357, 2010.

KRAUT, R. An aesthetic reading of Aristotle's ethics. In: HARTE, V.; LANE, M. Politeia in Greek and Roman Philosophy. New York: Cambridge University Press, 2013. p. 231-250.

LEAR, G. R. Plato on learning to love beauty. In: SANTAS, G. The Blackwell Guide to Plato's Republic. Malden: Blackwell Publishing, 2006a. p. 104-124.

Aristotle on moral virtue and the fine. In: KRAUT, R. The Blackwell Guide to Aristotle's Nicomachean Ethics. Malden: Blackwell Publishing, 2006b. p. 116-136.

LEAR, J. Katharsis. Phronesis, v. 33, n. 3, p. 297-326, 1988.

LEVINSON, J. What are aesthetic properties? In:

Contemplating Art: essays in aesthetics. Oxford: Clarendon Press, 2006. p. 336-351.

. Aesthetic supervenience. In: LEVINSON, J. Music, Art, and Metaphysics: essays in philosophical aesthetics. New York: Oxford University Press, 2011. p. 134-158.

Toward an adequate conception of aesthetic experience. In: LEVINSON, J. Aesthetic Pursuits: essays in philosophy of art. New York: Oxford University Press, 2016. p. 28-46.

MACKIE, J. L. Ethics: inventing right and wrong. London: Penguin Books, 1990. 
MCGINN, C. Ethics, Evil, and Fiction. Oxford: Clarendon Press, 2003.

MESKIN, A. Aesthetic testimony: what can we learn from others about beauty and art? Philosophy and Phenomenological Research, v. 69, n. 1, p. 65-91, 2004.

MITIAS, M. H. What makes an experience aesthetic? The Journal of Aesthetics and Art Criticism, v. 41, n. 2, p. 157169, 1982.

MOSS, J. What is imitative poetry and why is it bad? In: FERRARI, G. R. F. The Cambridge Companion to Plato's Republic. New York: Cambridge University Press, 2007. p. $415-444$.

MOTHERSILL, M. Beauty Restored. Oxford: Clarendon Press, 1984.

NUSSBAUM, M. C. The Fragility of Goodness: luck and ethics in greek tragedy and philosophy. New York: Cambridge University Press, v. Revisada, 2001.

PARIS, P. On form, and the possibility of moral beauty. Metaphilosophy, v. 49, n. 5, p. 711-729, 2018 a.

. The empirical case for moral beauty. Australasian Journal, v. 96, n. 4, p. 642-656, 2018 b.

PIAGET, J. O Juízo Moral da Criança. São Paulo : Summus, 1994.

PLATÃO. A República. 15a . ed. Lisboa: Fundação Calouste Gulbenkian, 2017.

RAPHAEL, D. D. The Moral Sense. London: Oxford 
University Press, 1947.

RIEGEL, N. Goodness and beauty in Plato. Archai, v. 12, p. 147-158, 2014.

ROGERS, K. Aristotle's conception of Tò Ka入óv. Ancient Philosophy, v. 13, n. 2, p. 355-371, 1993.

SAITO, Y. Everyday aesthetics. Philosophy and Literature, v. 25, n. 1, p. 87-95, 2001.

SHELLEY, J. The problem of non- perceptual art. The British Journal of Aesthetics, v. 43, n. 4, p. 363-378, 2003.

. The concept of the aesthetic. The Stanford Encyclopedia of Philosophy, 2017. Disponivel em: $<$ https://plato.stanford.edu/archives/win2017/entries/aesth etic-concept/>. Acesso em: 3 jun. 2020.

SIBLEY, F. Aesthetic and non-aesthetic. In: SIBLEY, F. Approach to Aesthetics: collected papers on philosophical aesthetics. New York: Oxford University Press, 2001. p. 33-51.

STECKER, R. Review of Art, Emotion Ethics, by Berys Gaut. The Journal of Aesthetics and Art Criticism, v. 66, n. 2, p. 199-201, 2008.

STOLNITZ, J. Aesthetics and Philosophy of Art Criticism: a critical introduction. Boston: Houghton Mifflin, 1960.

. On the origins of "aesthetic disinterestedness". The Journal of Aesthetics and Art Criticism, v. 20, n. 2, p. 131143, 1961.

TAYLOR, J. Hume on the standard of virtue. The Journal 
of Ethics, v. 6, n. 1, p. 43-62, 2002.

TOWNSEND, D. From Shaftesbury to Kant: the development of the concept of aesthetic experience. Journal of the History of Ideas, v. 48, n. 2, p. 287-305, 1987.

TOWNSEND, D. Hume's Aesthetic Theory: sentiment and taste. London: Routledge, 2001. 